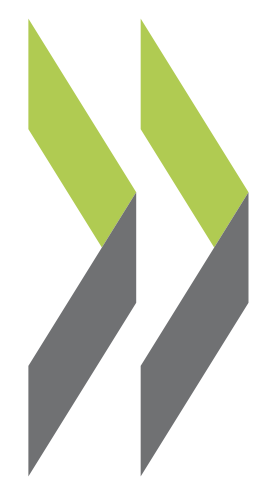

OECD Economics Department Working Papers No. 1412

\author{
Achieving strong \\ and balanced regional \\ development in India
}


Organisation de Coopération et de Développement Économiques

Organisation for Economic Co-operation and Development

25-Sep-2017

ECONOMICS DEPARTMENT

English - Or. English

\section{ACHIEVING STRONG AND BALANCED REGIONAL DEVELOPMENT IN INDIA}

ECONOMICS DEPARTMENT WORKING PAPERS No. 1412

By Isabelle Joumard, Hermes Morgavi and Hugo Bourrousse

OECD Working Papers should not be reported as representing the official views of the OECD or of its member countries. The opinions expressed and arguments employed are those of the author(s).

Authorised for publication by Alvaro Pereira, Director, Country Studies Branch, Economics Department.

All Economics Department Working Papers are available at www.oecd.org/eco/workingpapers.

JT03419321

Complete document available on OLIS in its original format

This document, as well as any data and map included herein, are without prejudice to the status of or sovereignty over any territory, to the delimitation of international frontiers and boundaries and to the name of any territory, city or area. 
OECD Working Papers should not be reported as representing the official views of the OECD or of its member countries. The opinions expressed and arguments employed are those of the author(s).

Working Papers describe preliminary results or research in progress by the author(s) and are published to stimulate discussion on a broad range of issues on which the OECD works.

Comments on Working Papers are welcomed, and may be sent to OECD Economics Department, 2 rue André Pascal, 75775 Paris Cedex 16, France, or by e-mail to eco.contact@ oecd.org.

All Economics Department Working Papers are available at www.oecd.org/eco/workingpapers.

This document and any map included herein are without prejudice to the status of or sovereignty over any territory, to the delimitation of international frontiers and boundaries and to the name of any territory, city or area.

The statistical data for Israel are supplied by and under the responsibility of the relevant Israeli authorities. The use of such data by the OECD is without prejudice to the status of the Golan Heights, East Jerusalem and Israeli settlements in the West Bank under the terms of international law.

\section{(C) OECD (2017)}

You can copy, download or print OECD content for your own use, and you can include excerpts from OECD publications, databases and multimedia products in your own documents, presentations, blogs, websites and teaching materials, provided that suitable acknowledgment of OECD as source and copyright owner is given. All requests for commercial use and translation rights should be submitted to rights@oecd.org 
ECO/WKP(2017)42

\section{ABSTRACT/RÉSUMÉ \\ Achieving strong and balanced regional development in India}

While India's per capita income is converging towards that of the richer countries, inequality has drifted up. Spatial inequality - across states and between urban and rural areas - is pronounced, with large differences in output per capita and in access to core public services, such as electricity, roads, and education. Implementing the GST will contribute to reduce trade barriers across states while recent changes in the federalism model are empowering states and promoting experimentation. Prompting states to modernise product and labour market regulations should allow firms in the organised sector to reach an efficient size, and promote job creation and rising incomes in all states. Raising the living standards in poorer states would also require increasing productivity in the agricultural sector by supporting farm consolidation and improving infrastructure in rural areas, particularly roads that connect villages to market towns, crop storage infrastructure and access to sustainable irrigation technologies. As working population moves out of agriculture, urbanisation will gather pace. However, exploiting cities' potential for job creation, productivity gains and improvement in the quality of life would require better physical and social urban infrastructure. Local spending and regulatory competences should be clarified. Performance of local bodies should be assessed regularly to make them accountable. Municipalities should also be granted clear revenue-raising power (in particular property taxes and user charges for urban infrastructure) to enable them to fund better public infrastructure and services.

This working Paper relates to the 2017 OECD Economic Survey of India

(www.oecd.org/eco/surveys/economic-survey-india.htm)

JEL codes: $\mathrm{H} 7, \mathrm{I} 13, \mathrm{O} 13, \mathrm{O} 18, \mathrm{O} 4, \mathrm{Q} 1, \mathrm{R} 1, \mathrm{R} 5$

Keywords: India, federalism, regional development, inequality, agriculture, productivity, urbanisation

\section{Vers un développement régional solide et équilibré en Inde}

Si en Inde, le revenu par habitant est train de s'aligner sur celui de pays plus riches, les inégalités se sont très fortement accentuées. Les inégalités spatiales (entre États d'une part et entre zones urbaines et zones rurales d'autre part) sont très marquées, avec de grandes disparités en termes de production par habitant et d'accès aux services publics de base comme l'électricité, les routes ou l'éducation. L'application de la taxe sur les biens et services (GST) contribuera à réduire les obstacles entre États, tandis que les modifications récentes apportées au modèle du fédéralisme donnent davantage de pouvoir aux États et sont propices à l'expérimentation. Inciter les États à moderniser la réglementation des marchés de produits et des marchés du travail devrait permettre aux entreprises du secteur formel d'atteindre une taille efficiente, et devrait favoriser la création d'emplois et la hausse du revenu dans tous les États. Relever les niveaux de vie dans les États les plus pauvres nécessiterait aussi d'accroître la productivité dans le secteur agricole en appuyant l'agrandissement des exploitations et en améliorant les infrastructures dans les zones rurales, notamment les routes reliant les villages aux villes abritant des marchés ou les dispositifs de stockage des récoltes, ainsi que l'accès à des technologies d'irrigation durables. À mesure que la main-d'œuvre va délaisser le secteur agricole, l'urbanisation va s'accélérer. Cependant, exploiter le potentiel de création d'emplois, de gains de productivité et d'amélioration de la qualité de vie offert par les villes exigerait la mise en place d'infrastructures urbaines sociales et physiques de meilleure qualité. Il conviendrait à cet égard de clarifier les compétences locales en matière de dépenses et de réglementation. La performance des organismes locaux devrait être régulièrement évaluée de manière à ce qu'ils puissent être tenu de rendre des comptes. Les municipalités devraient également se voir octroyer des pouvoirs précis en matière de collecte de recettes (en particulier de taxes foncières et de redevances d'utilisation des infrastructures urbaines), ce qui leur permettrait de mieux financer les infrastructures et services publics.

Ce document de travail fait référence à l'édition 2017 de la publication Étude économique de l'OCDE: Inde (www.oecd.org/eco/surveys/economic-survey-india.htm)

Classification JEL : H7, I13, O13, O18, O4, Q1, R1, R5

Mots-clés : Inde, fédéralisme, développement régional, inégalités, agriculture, productivité, urbanisation 


\section{TABLE OF CONTENTS}

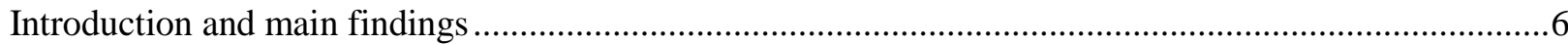

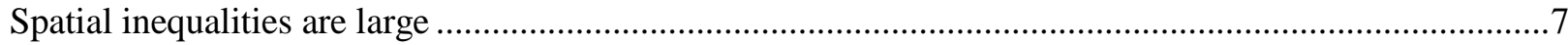

Inequality across states has increased and is high by international standards .......................................

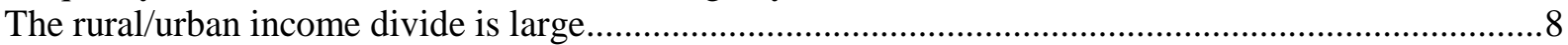

Differences for non-income dimensions are even larger between rural and urban areas .........................9

Output inequality across states: drivers and policies to address them ..............................................10

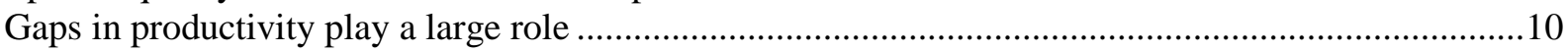

Promoting productivity growth in all Indian states.............................................................................

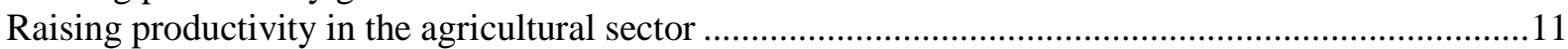

Shifting resources to high productivity sectors, in particular organised manufacturing .......................18

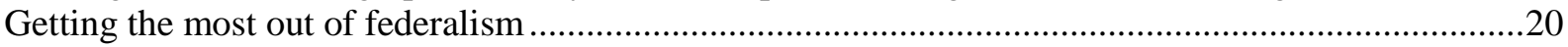

Building up infrastructure and human capital across states ...............................................................23

Reforming product and labour market regulations at the state level ...................................................23

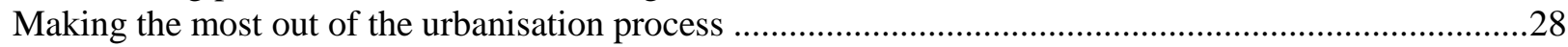

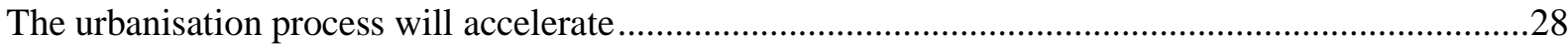

Urbanisation can spur productivity and better respond to citizens' needs ...........................................29

Meeting infrastructure needs and addressing air pollution in urban areas ..........................................29

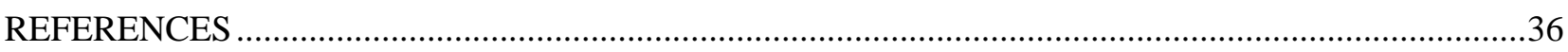

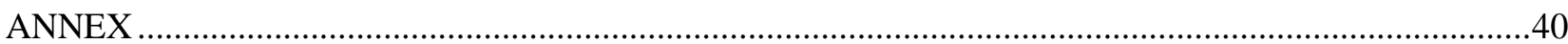

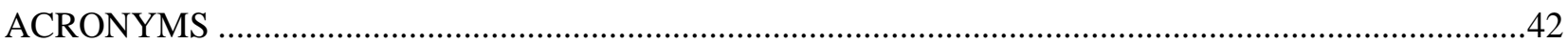

\section{Tables}

1. Agricultural households: size of land holdings, income, investment and indebtedness ...................17

2. Percentage of inequality explained by disparities across states and the urban/rural divide................41

\section{Figures}

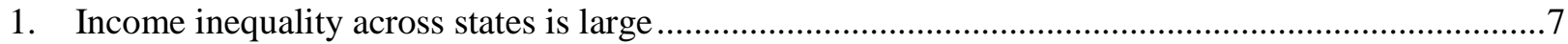

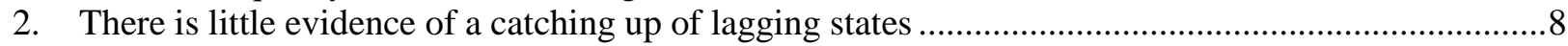

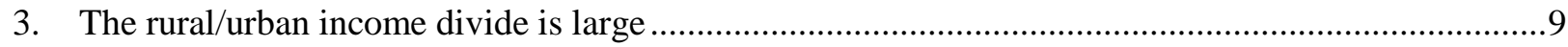

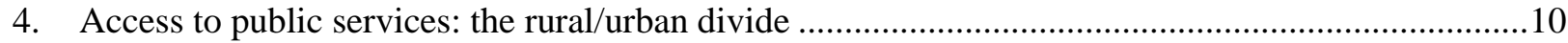

5. Gaps in GDP per capita across states are largely due to productivity differences.............................13

6. Explaining growth patterns across states over the period 2000-01 to 2011/12 …...........................14

7. Agriculture: a key factor behind income dispersion across states ...............................................15

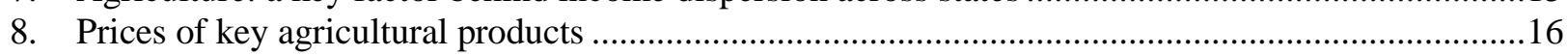

9. Firms, employment, value added and productivity in organised and unorganised manufacturing....19

10. Tax and spending autonomy of States: India compared with 14 other federations...........................20

11. The quality of physical and social infrastructure varies significantly across states .........................24

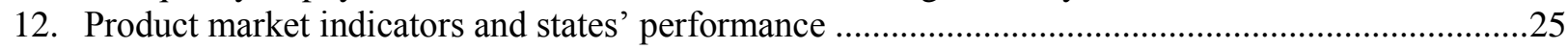

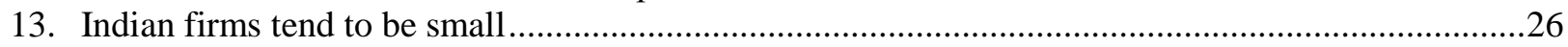

14. Some states do better than others in allocating resources across firms from the organised sector ....27

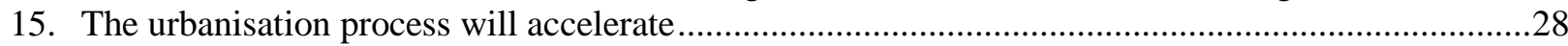

16. Potential urbanisation gains are not fully exploited ........................................................................30 
17. Urbanisation challenges: infrastructure shortages and local air pollution 31

\section{Boxes}

Box 1. Understanding differences in GDP per capita across countries and states................................11

Box 2. Minimum support prices and tariff/border measures for agricultural products.............................16

Box 3. Organised versus unorganised manufacturing sectors: definition and contribution

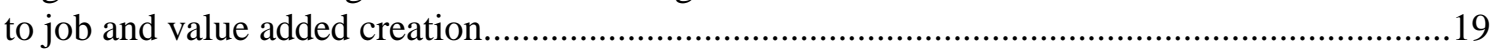

Box 4. The move to a more co-operative and competitive federalism framework ..................................21

Box 5. Rajasthan: recent policy reforms to promote economic development .....................................22

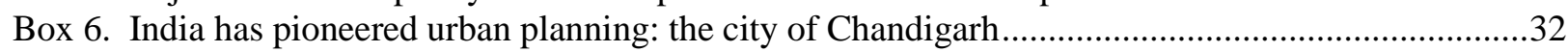

Box 7. Recent initiatives to improve urban infrastructure in India..........................................................33

Recommendations for achieving strong and balanced regional development .........................................35 


\title{
ACHIEVING STRONG AND BALANCED REGIONAL DEVELOPMENT IN INDIA
}

\author{
By Isabelle Joumard, Hermes Morgavi and Hugo Bourrousse ${ }^{1}$
}

\section{Introduction and main findings}

A key achievement of India is the decline in absolute poverty (Bhagwati and Panagariya, 2013): around $12 \%$ of the population (140 million people) was lifted out of poverty between 2004/5 and 2011/12, of which 120 million lived in rural areas (GoI, 2015). Despite this progress, poverty and income inequality remain high. The number of people living below poverty line is geographically concentrated in rural areas and in urban slums. The poverty rate is also much higher in some states. The gap in GDP per capita between states is large and has widened.

Recent changes in India's federalism model have given states more freedom to modernise regulations while the implementation of the landmark GST reform will contribute to make India a single market. The top-down, planning approach, to federalism has been replaced by a bottom-up approach, promoting experimentation and the sharing of experience across states, as the National Institution for Transforming India, NITI Aayog, replaced the Planning Commission. In addition, states are now ranked on the ease of doing business and some have taken the lead in reforming labour and land regulations. The financing system has also changed, as per the recommendations of the $14^{\text {th }}$ Finance Commission, with various conditional and earmarked grants replaced by a larger share of the divisible tax pool, empowering the states to tailor public services to local needs. These reforms give each state, even the poor, more freedom and incentives to reform. Reducing spatial disparities further will require however additional reforms.

This paper first shows that the spatial component of poverty and inequality is sizeable. Spatial inequality in output per capita is often accompanied by inequality in access to core public services. Rural areas fare particularly poorly in this respect. The paper then reveals that inequality across states largely reflects the activity mix - in particular the agriculture share in output - and large productivity gaps. Despite the many programmes to support the agriculture sector, productivity is low.

The lack of qualifications, combined with the low number of job openings, has slowed the transition from agriculture to other more productive activities. Large gaps in productivity across states also arise in the organised manufacturing sector, partly driven by policy, including social and physical infrastructure but also product market regulations (PMRs) that differ across states. Improving the ease of doing business, as promoted by the Make in India initiative, coupled with federalism reforms, could have a significant impact on incomes and job creation.

Finally, the paper shows that the transition out of agriculture, large disparities in living standards between rural and urban areas and demographic factors will result in a massive urbanisation process. It suggests reform options to ensure that India gets the most out of urbanisation, in particular more and better jobs and higher productivity, while minimising adverse effects (including urban deprivation and pollution).

1. Authors were all at the OECD Economics Department at the time of writing. They thank Indian officials, members of the Economic and Development Review Committee, Alvaro Pereira, Robert Ford, Peter Hoeller, Piritta Sorsa and Hansjörg Blöchliger from OECD Economics Department ,and Joaquim Oliveira Martins and Rudiger Ahrend from OECD Centre for Entrepreneurship, SMEs, Local Development and Tourism, for their valuable comments. This paper also benefitted from a contribution by Daniela Glocker. Special thanks are due to Anthony Bolton and Assa Fofana, from OECD Economics Department, for secretarial assistance. 


\section{Spatial inequalities are large}

\section{Inequality across states has increased and is high by international standards}

Several indicators can be used to measure regional disparities across states. The OECD commonly uses the Gini index of regional GDP per capita, with equal weights for each region/state regardless of its population size. The index focuses on output rather than income and does thus not include government transfers and remittances from richer to poorer areas. Using this metric, India's regional disparities are large compared with the OECD average, as is the case in many other emerging economies (Figure 1.A). In 2013, output per capita in the poorest state (Bihar) was just 13\% the level of Delhi, one of the richest territories. Although the regional Gini index for India is broadly at par with China, the share of the population living in low-income regions in India is much higher (Figure 1.B), making poverty a more pressing issue.

Figure 1 Income inequality across states is large

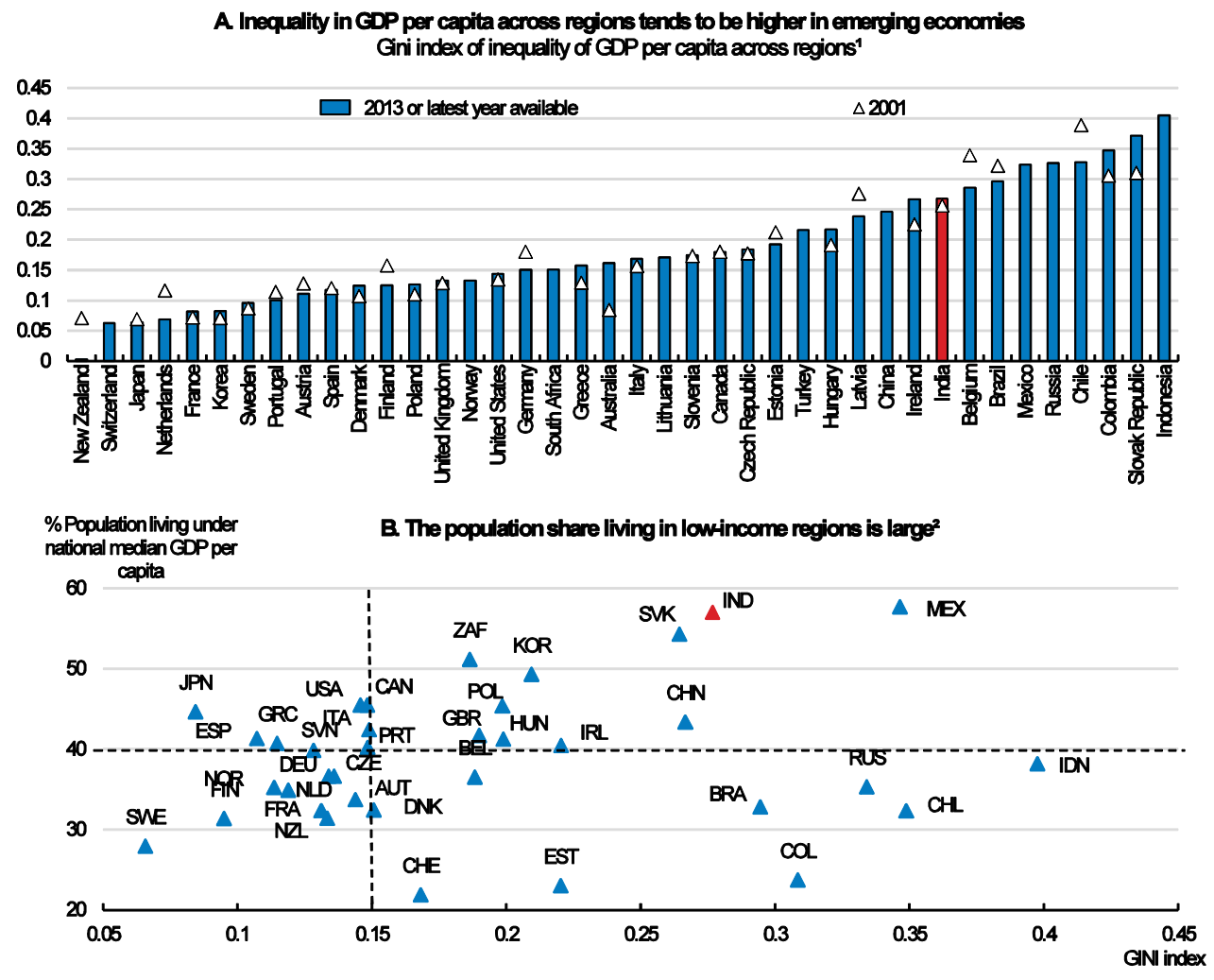

1. The Gini index is a measure of inequality among all regions of a given country. The index takes on values between 0 and 1 , with zero interpreted as no disparity. It assigns an equal weight to each region regardless of its size. Differences in the values of the index among countries may partly reflect differences in the size of regions in each country.

2. The dashed lines show the median for the corresponding indicators.

Source: OECD Regions at a Glance 2013; and OECD Regional Economy database.

Not only are regional disparities pronounced, they have even increased since the 1990s (Ahluwalia 2000; Sachs et al., 2002). Using output measures reveals that states with a low GDP in 2000 have tended to grow less rapidly than those with a higher GDP per capita (Figure 2.A). This is also reflected in the increase of the regional Gini coefficient, be it adjusted or not for the size of the population (Figure 2.B). Using consumption data from the NSSO household surveys displays the same pattern, with a drift-up in 
regional Gini coefficient. There are exceptions, however, suggesting that policy matters. Bihar, for instance, is a very poor state but signs of catch-up have emerged recently: its per capita income stood at $41 \%$ of India's average in FY 2013-14, up from 32\% in 2005-06. And the poverty rate has also fallen more than in most other Indian states. Likewise, Rajasthan's per capita income increased from $80 \%$ of India's average in FY 2005/06 to 90\% in 2013/14.

Figure 2 There is little evidence of catching up of lagging states

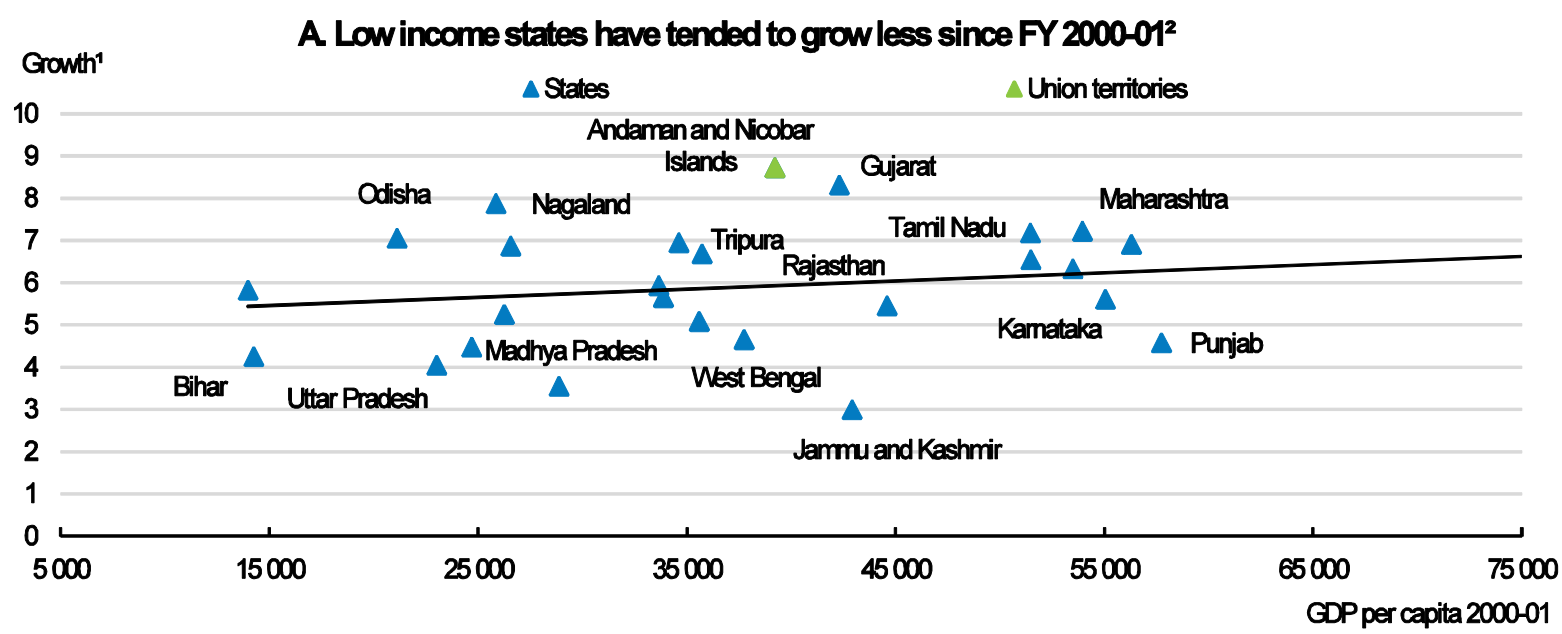

B. Weighted and unweighted Ginis across states over time²

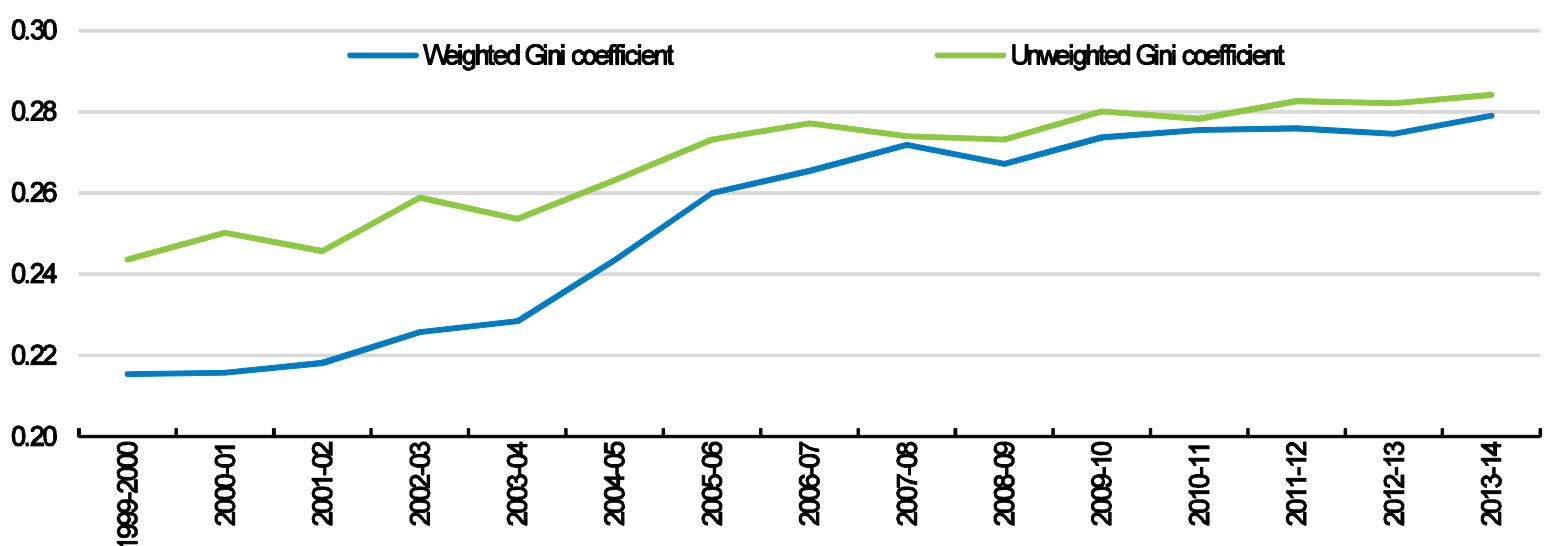

1. Average annual growth of GDP per capita over the period 2000-01/2014-15 at constant prices. India comprises 29 states, which have their elected governments, and 7 union territories, which, unlike the states, are ruled directly by the central government.

2. The population data are from Census 2001 and 2011. For the other years, population was estimated by linear interpolation and extrapolation.

Source: Central Statistics Office; and NSSO.

\section{The rural/urban income divide is large}

The urban/rural divide accounts for a large share of India's spatial income inequality (Annex 1). In the early 2010s, the fastest growing states tend to be those with a large urban population (Figure 3.A) and the richest states are the most urbanised. Still, India has lagged behind other BRIICS countries on urbanisation. Rural poverty is both widespread and severe, largely reflecting the very low agricultural productivity. 
Poverty in rural areas often results in forced migration to cities, distress sales of land and, in extreme cases, suicides. Overall, the absolute poverty rate in rural areas, at $26 \%$ in 2011/12, was almost twice the poverty rate in urban areas (Figure 3.B), despite a faster decline since the mid-2000s.

Figure 3 The rural/urban income divide is large

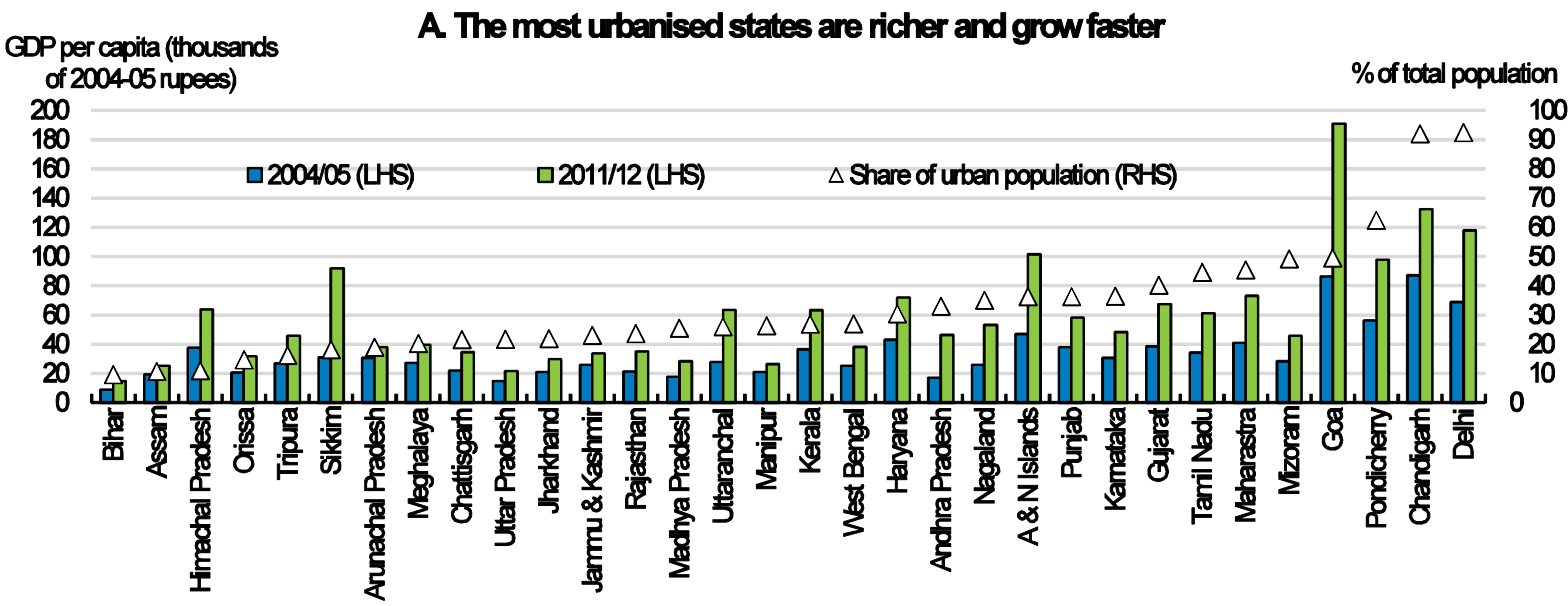

B. The poverty rate is often much larger in rural areas

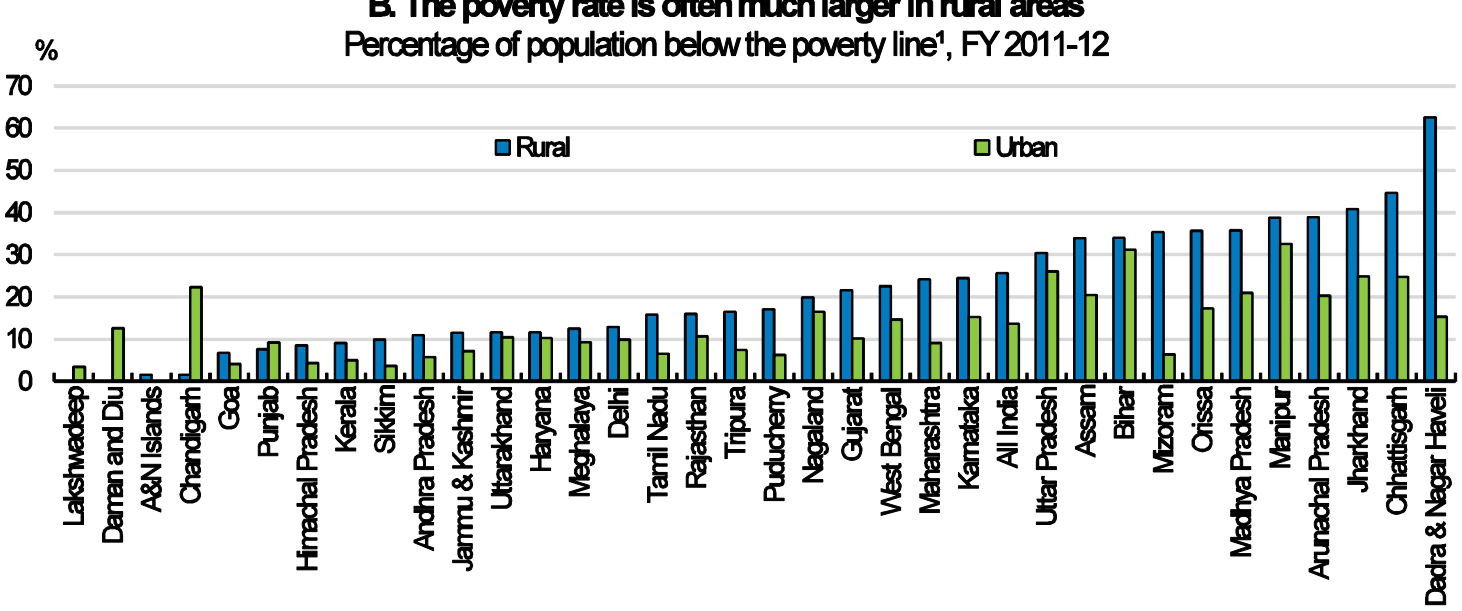

1. Poverty is calculated by using the Tendulkar methodology, which expresses the poverty line in terms of monthly per capita consumption expenditure based on a mixed reference period.

Source: Central Statistics Office of India; and Indian Census, for panel A; and Reserve Bank of India, for panel B.

\section{Differences for non-income dimensions are even larger between rural and urban areas}

Access to public services, in particular water provision and sanitation, electricity and health care facilities, is a key element of well-being. These services are also important drivers of growth. In India, population coverage for these services has improved, but remains low by BRIICS standards. The government has developed methodologies, including human development criteria, to gauge states' development level and needs and allocate central government transfers (Government of India, 2013). The Oxford Multidimensional Poverty Index suggests that deprivation in education, health and living standards (which covers various aspects of living condition such as electricity and sanitation) is even higher than in 
income (OPHI, 2015). Access to core public services is also highly spatially concentrated, with $69 \%$ of the rural population multi-dimensionally poor compared with $31 \%$ in urban areas. The rural/urban divide is particularly marked for electricity and sanitation (Figure 4).

Figure 4 Access to public services: the rural/urban divide

Percentage of population who are multidimensional poor by location

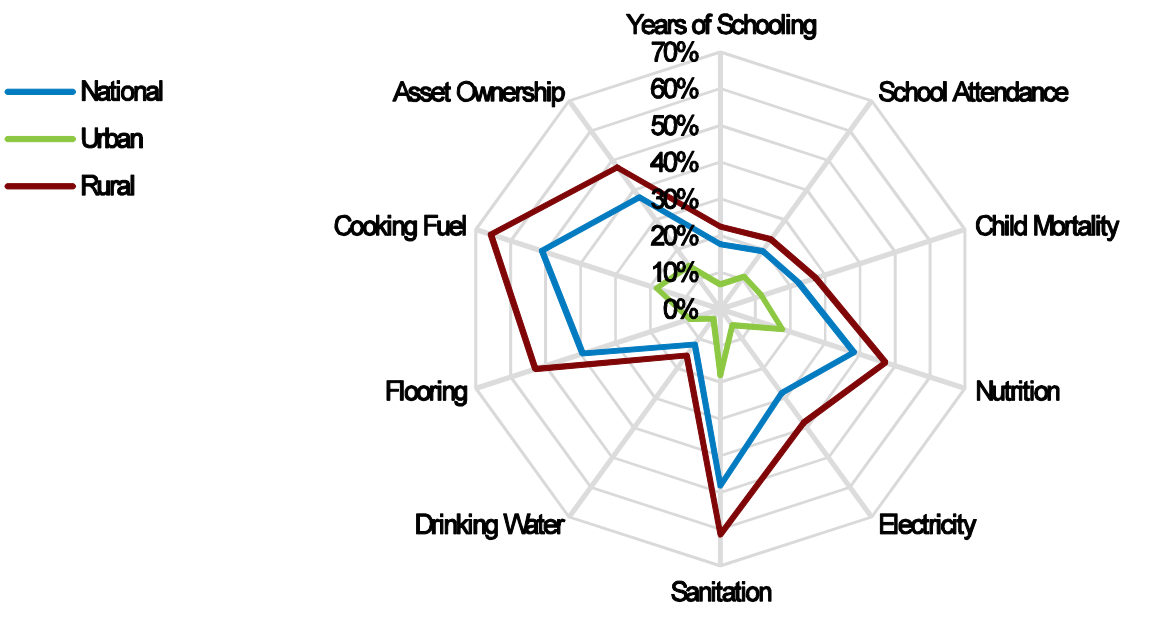

Note: The multidimentional poverty index uses 10 indicators to measure poverty in three dimensions: education, health and living standards (electricity, sanitation, drinking water, floor, cooking fuel, assets). This chart shows the percentage of population who are poor on each of the ten dimensions.

Source: Oxford Poverty and Human Development Initiative (2015), Global Multidimensional Poverty Index Databank. OPHI, University of Oxford.

Access to health care also varies significantly across states and between rural and urban areas (OECD, 2014a). Life expectancy has improved and the disparity in life expectancy between rural and urban areas has declined. Still, rural areas and urban slums lack an adequate number of health professionals (Sharma, 2015). While OECD work based on cross-country comparisons suggests that the income level is an important determinant of the population health status (OECD, 2010), drawing comparisons across states in India reveals that the population in poorer states does not consistently have a lower life expectancy. As an example, life expectancy at birth is significantly higher in Kerala (74 years) than in richer Haryana (67 years). Health care provision is mainly under the states' responsibility. However, poor states do not systematically fare poorly as regard the number of hospital beds per capita, suggesting that states' policies and priorities matter.

\section{Output inequality across states: drivers and policies to address them}

\section{Gaps in productivity play a large role}

Gaps in GDP per capita, both across countries and across states, can be decomposed into differences in productivity, labour resource utilisation and demographics (Box 1). The OECD publication Going for Growth reveals that income per capita in India, like in other BRIICS countries, is much lower than in OECD countries. India's employment rate is relatively low but raising labour productivity is an even more important challenge. Within India, the same analysis reveals that differences in productivity are also by far the most important factor driving differences in per capita output across states (Figure 5). 
Productivity in the three poorest states (Bihar, Uttar Pradesh and Assam) was less than one third the level of Haryana.

\section{Box 1. Understanding differences in GDP per capita across countries and states}

Gaps in GDP per capita level can be decomposed into:

- Productivity (GDP per employed person);

- Employment rate (employed person to working age population);

- Demographic factors (working-age to total population)

Similarly, differences in GDP per capita growth across states can be decomposed into: differences in productivity gains, changes in employment rates as well as a demographic dividend.

The employment rate tends to be higher in poorer states as the economic participation of women often decreases as household income rises (OECD, 2014a). In contrast, demography, as measured by the working-age to total population ratio, tends to be slightly more favourable in richer states, though again differences across states are small.

Focusing on growth patterns across states, three main messages emerge:

- Productivity gains are key. Most of the growth in GDP per capita across states over the period 2000/01 to 2011/12 is explained by productivity gains (Figure 6).

- All the 34 Indian states and territories have benefited from a "demographic dividend" - the share of the working age in total population increased by 4.5 percentage points for India as a whole and by more than 5 percentage points in some states and territories (including Delhi, Haryana, Punjab and Rajasthan). However, states with faster growing workforces have not performed better in terms of per capita income growth. Structural bottlenecks have likely impeded the transformation of favourable demographics into job creation and output growth.

- The employment rate declined in a large majority of states (Kerala is one of the few exceptions), with slightly higher education attendance accounting for only a small fraction of the overall decline (OECD, 2014a).

\section{Promoting productivity growth in all Indian states}

Each Indian state can introduce reforms to boost productivity and thus the well-being of its population. Priorities will, however, differ according to the size of the agricultural sector, the quality of human and social infrastructure, as well as product and labour market regulations which are mostly set at the state level in India.

\section{Raising productivity in the agricultural sector}

Raising productivity in agriculture is key to boosting incomes in poorer states and reducing poverty in rural areas. Differences in productivity across states are highly correlated with the weight of agriculture in the state's economy (Figure 7.A). Employment in agriculture, at $49 \%$ of total employment in 2012, is still very high by BRIICS standards while productivity is low (Figure 7.B\&C). Rice yield in India is just 55\% of rice yield in China and much lower than other major rice producing countries like Bangladesh, Indonesia and Vietnam (NITI Aayog, 2015). The average yield for the main food grains, wheat and rice, 
which are grown on the most fertile and irrigated areas in the country, are significantly below Chinese yield (Government of India, 2016).

Many farmers are extremely poor (Government of India, 2014): $36 \%$ of agricultural households live below poverty line and an additional 5\% are in extreme poverty (i.e. entitled to an Antyodaya ratio card giving them access to highly subsidised food). They are poorly equipped and their crops are heavily dependent on seasonal rains.

A wide range of input subsidies, price support and other supply-side programmes have been used to support farmers and stabilise consumption prices (Box 2). Fertiliser subsidy is the second largest subsidy in the central government budget after food and petroleum, amounting to 0.5\% of GDP in FY 2015/16. The generous subsidy to urea has led to a high use of nitrogen fertilisers (Figure 7.D), polluting water resources. Since other nutrients, phosphates and potassium, receive subsidy per active unit, the overall use of fertilisers is unbalanced, which affects soil fertility. Urea subsidies may also have led to a misallocation of resources as agricultural commodities which are less fertiliser intensive receive less support. They have also led to misuses, like smuggling to neighbouring countries and use for non-agricultural purposes (Gulati and Banerjee, 2015).

To promote a more effective use of fertilisers and to raise productivity, the government has recently intensified technical assistance to farmers. The government has required urea producers to shift to neem coated urea for the subsidised part of the production since 2015 and has asked states to educate farmers on the benefits and use of neem coated urea. Soil Health Cards launched in February 2015, with crop-wise recommendations for nutrients and fertilisers, should be provided to all 140 million farm households within three years. Progress across states has been uneven so far - Tamil Nadu, Gujarat, Andhra Pradesh and Haryana have taken the lead. This welcome initiative should be accompanied by a gradual replacement of fertiliser subsidies, which mostly benefit fertiliser manufacturers, by a direct cash transfer targeted at poor farmers.

Loan subsidies have failed to give a durable boost to productivity. Agriculture figures prominently on the list of Priority Sector Lending, with a target of $18 \%$ of overall commercial bank lending. The government also provides a $2 \%$ subsidy on short-term crop loans of up to INR 300000 and an extra $3 \%$ for the prompt re-payment of loans. This subsidy, by discriminating against long-term loans, has impeded long-term investment and thus failed to boost productivity. In addition, agricultural loans have often failed to reach small farmers who continue to depend on expensive money lenders. 
Figure 5 Gaps in GDP per capita across states are largely due to productivity differences
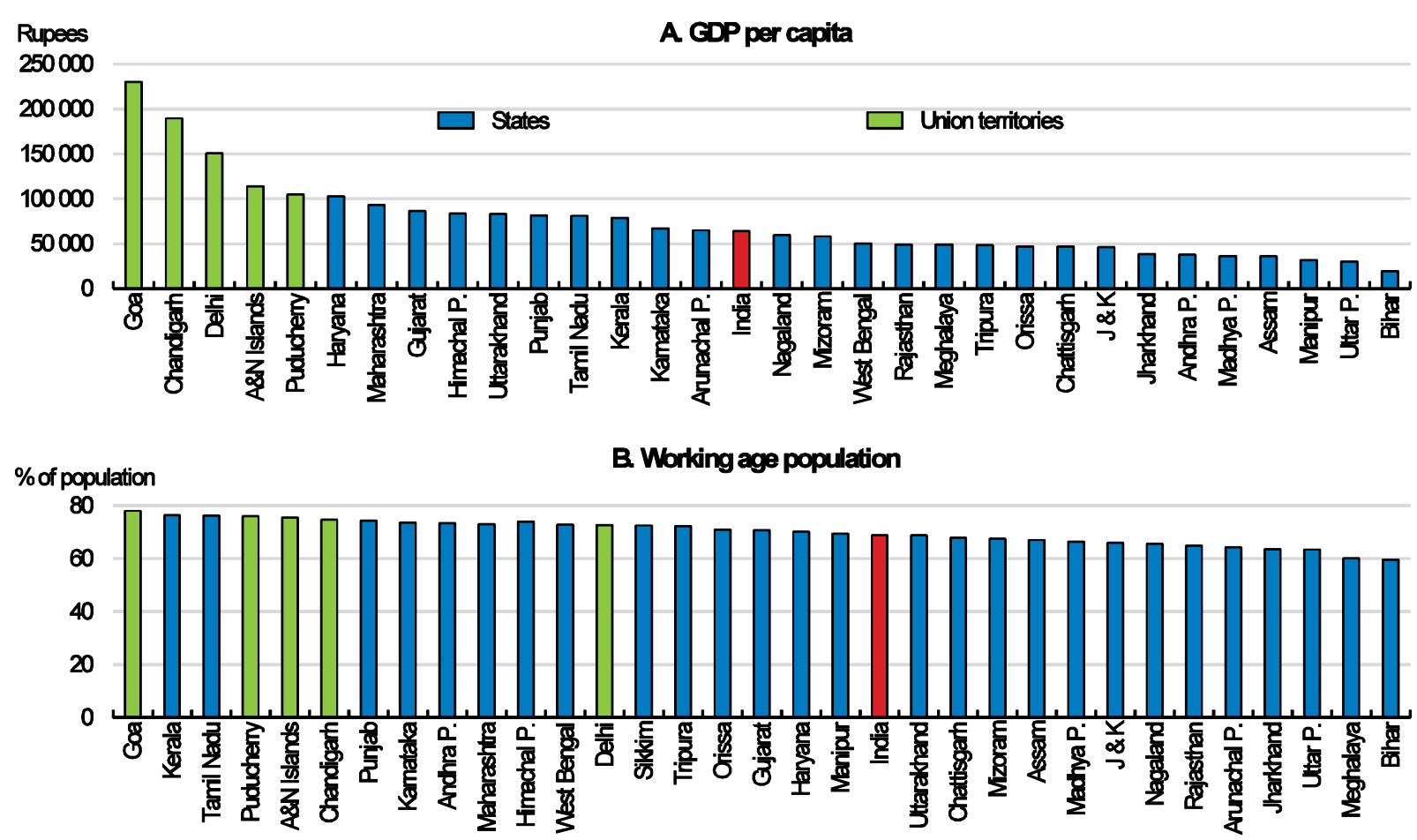

$\%$ of working age population

C. Employment rate
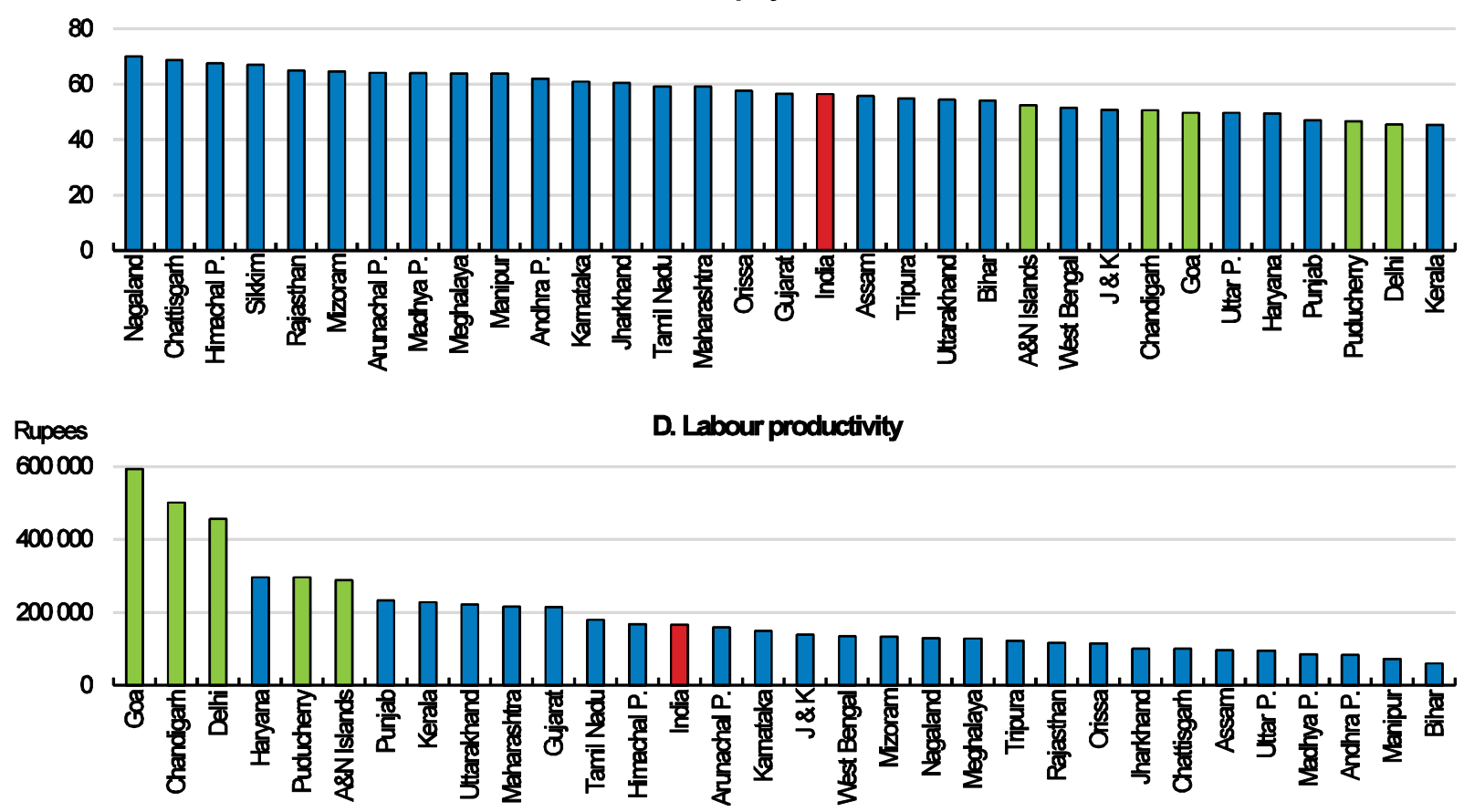

Note: The working age population ratio is the percentage of population aged 15 or older as a per cent of the total population; the employment rate is the number of employed as a per cent of the population aged 15 or older; labour productivity is measured in terms of GDP per worker. Data refer to 2011. For Sikkim, the GDP and productivity data are not shown as they present anomalies. P. stands for Pradesh. J\&K stands for Jammu and Kashmir.

Source: Central Statistics Office of India; and Census of India. 
Figure 6 Explaining growth pattern across states over the period 2000-01 to 2011-12

\section{A. Growth in GDP per capita at constant prices}

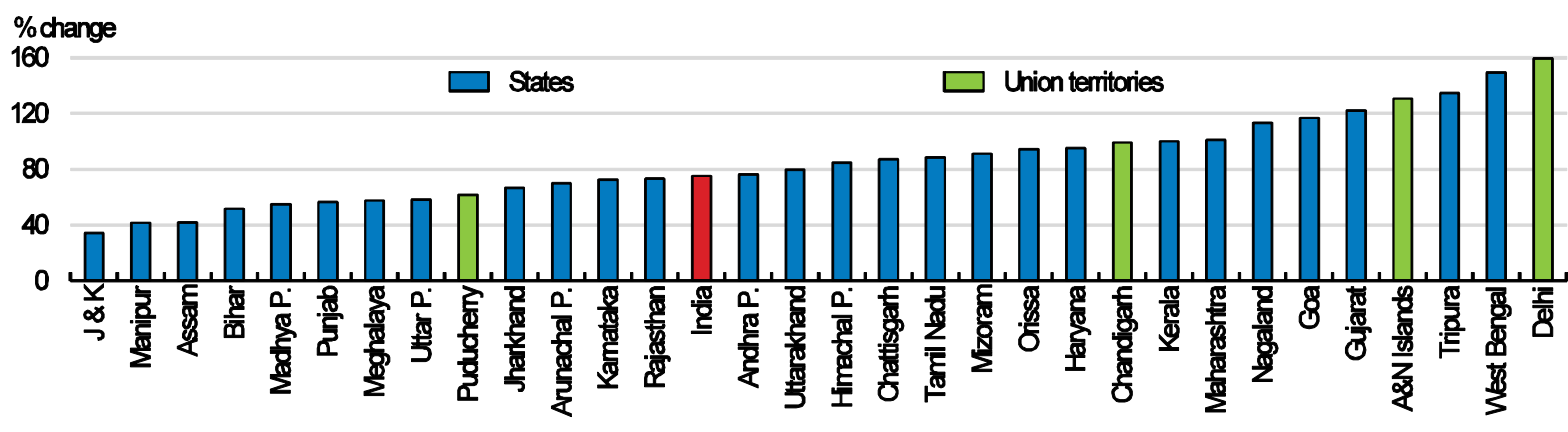

B. Productivity gains

$\%$ change

300

200

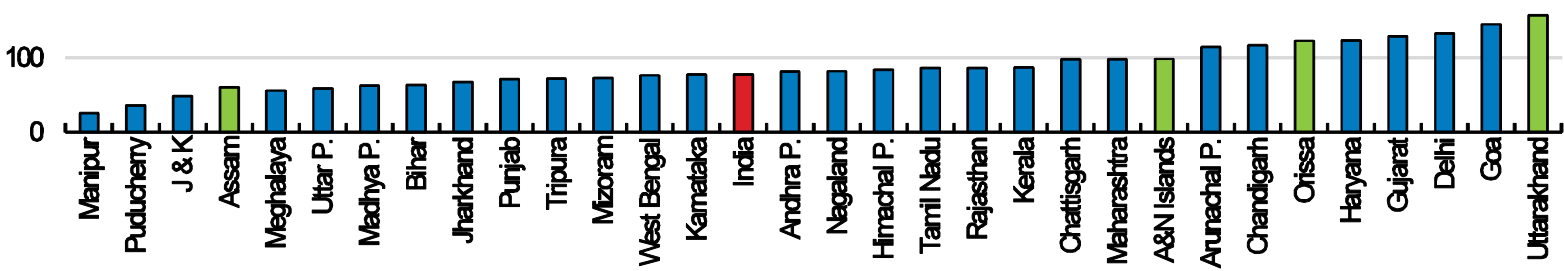

Percentage points

C. Change in employment rate

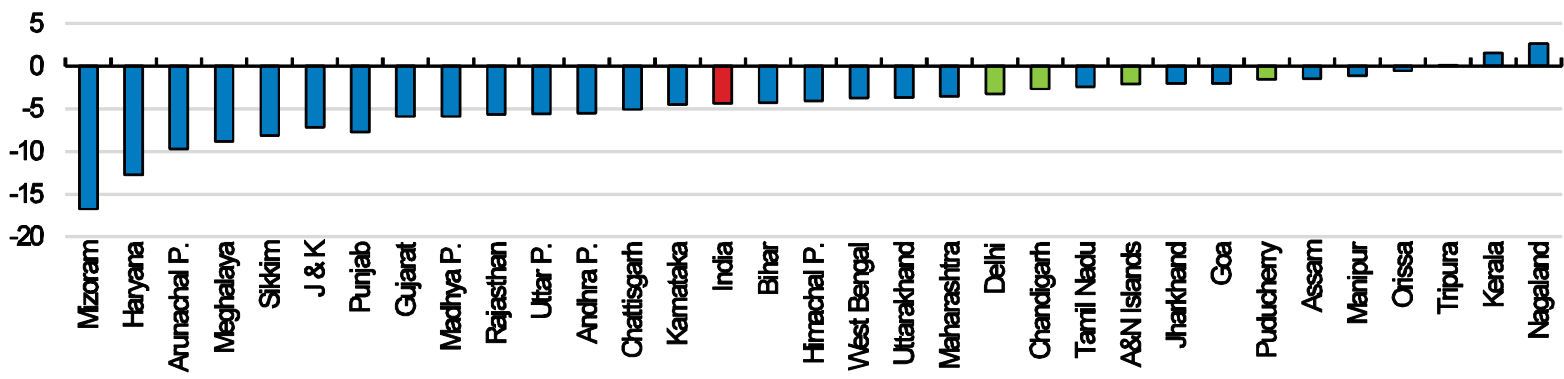

D. Demographic dividend (variation in the working age to total population ratio)

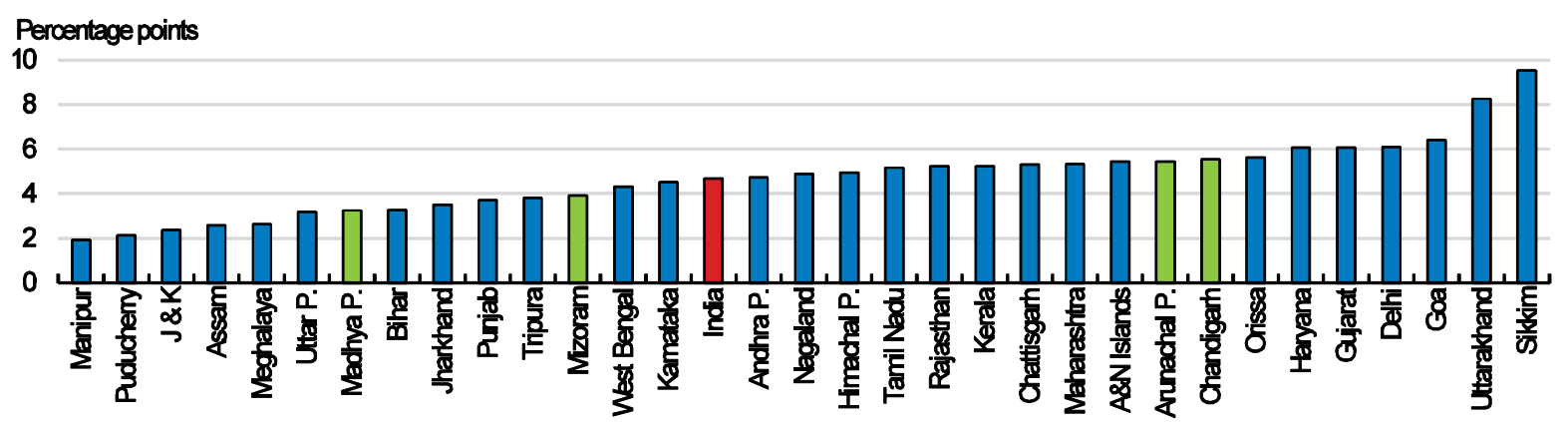

Note: The working age population ratio is the percentage of population aged 15 or older on total population; the employment rate is the ratio of the total number of employees on population aged 15 or older; labour productivity is measured in terms of GDP per worker. Data refer to 2011. For Sikkim, the GDP and productivity data are not shown as they present anomalies. P. stands for Pradesh. J\&K stands for Jammu and Kashmir.

Source: Census of India; and Central Statistics Office of India. 
Figure 7 Agriculture: a key factor behind income dispersion across states

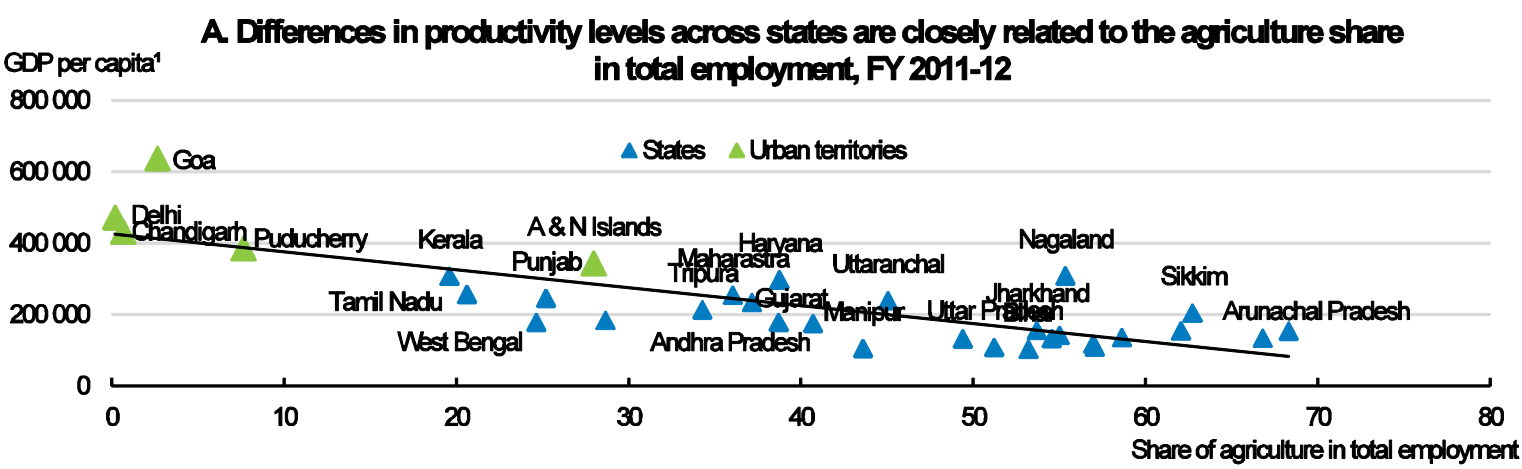

$\%$ of total employment

B. Agriculture absorbs a large share of total employment

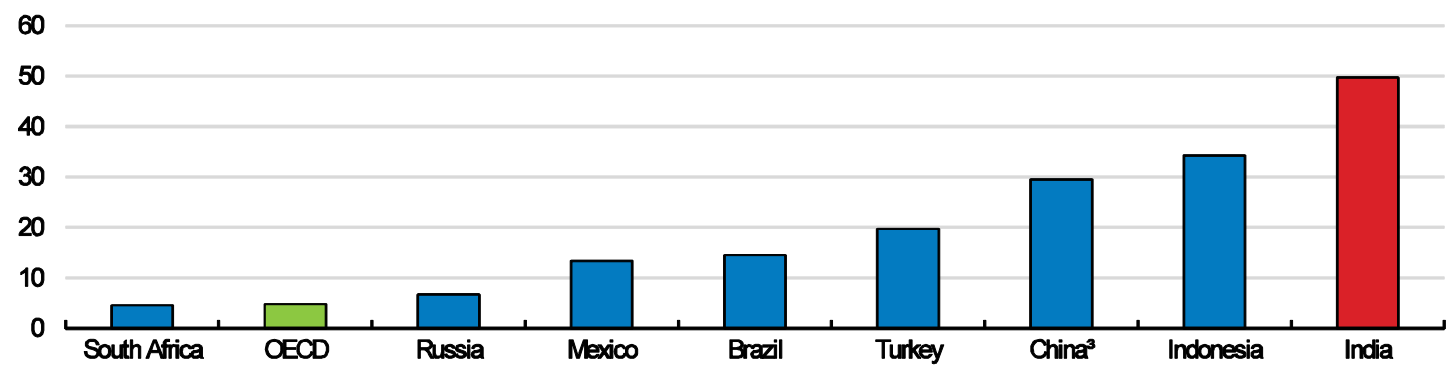

GDP per employee in agriculture ${ }^{2}$

C. Productivity in agriculture is low

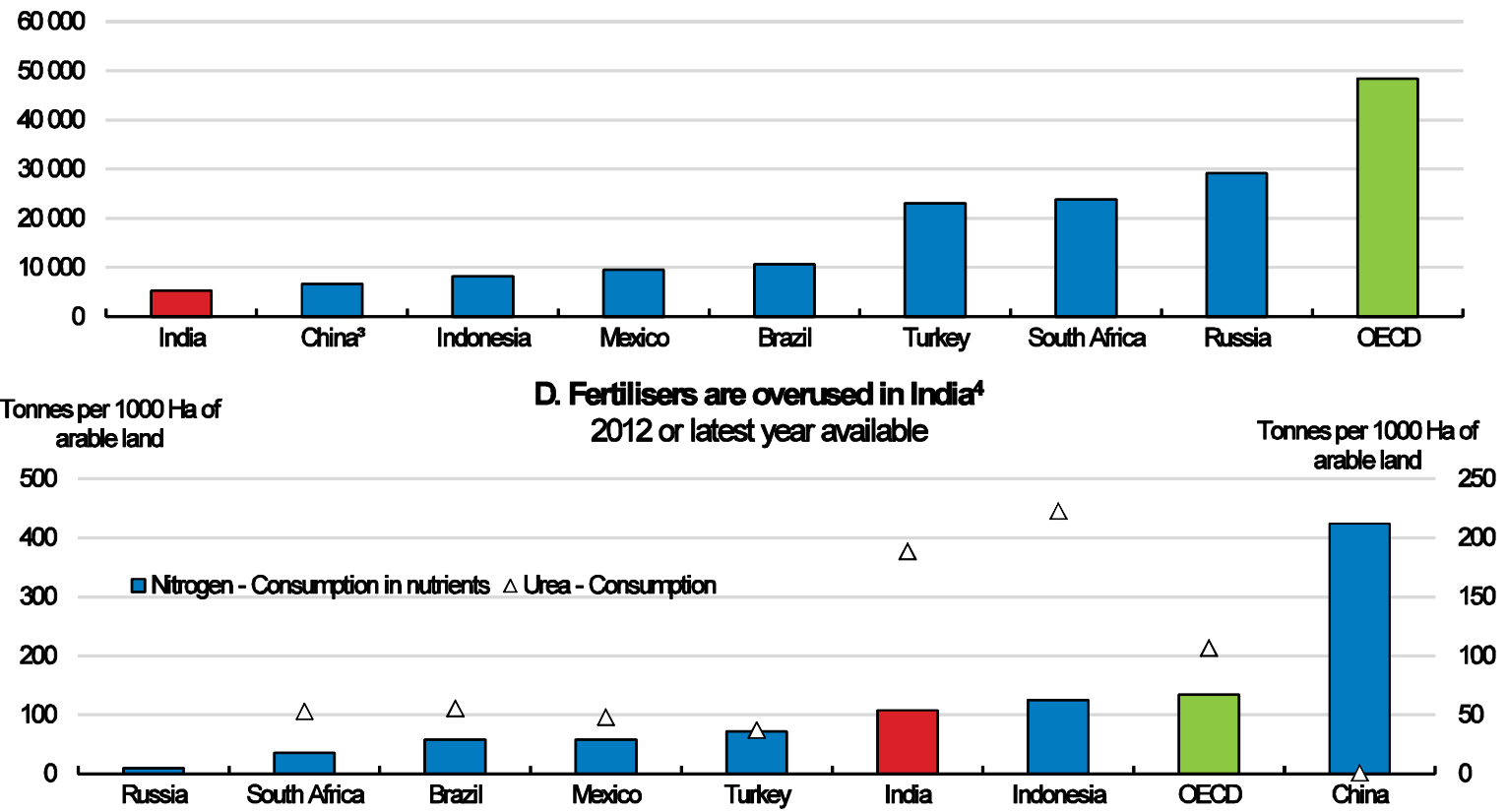

1. In current rupees per capita.

2. In constant PPP USD per employee.

3. Employment data for China refer to the primary sector (including farming, forestry, animal husbandry and fishery).

4. Consumption refers to the quantity of fertilisers consumed for agriculture production, expressed in product weight. Consumption in nutrients is calculated based on the quantity of nutrients contained in the fertilisers used.

Source: NSSO, for panel A; World Bank and National Bureau Statistics of China, for panels B and C; and FAO, for panel D. 


\section{Box 2. Minimum support prices and tariff/border measures for agricultural products}

The Agricultural Prices Commission was set up in 1965 to advise the government on price policy for agricultural commodities. Currently the Commission sets Minimum Support Prices (MSPs) for 24 commodities and a Fair and Remunerative Price for sugarcane. The MSPs for all commodities increased sharply after 2007-08, after a long period of near stagnation (Figure 8.A). Procurement has been used in some cases to ensure that prices do not fall below the MSPs. Large public stocks have created challenges, with large food wastage reflecting inappropriate storage and distribution. Recently, the active management of food stocks has contributed to reduce food price pressures.

The operation of MSPs also relies on tariff/border measures. Tariffs on a number of commodities were lowered after 2008. In 2015 , tariffs stood at $50 \%$ for wheat, $80 \%$ for rice and $31 \%$ for meat. Export bans were also implemented for rice and wheat to reduce price volatility and ensure a stable domestic supply (Figure 8.B).

Figure 8 Prices of key agricultural products

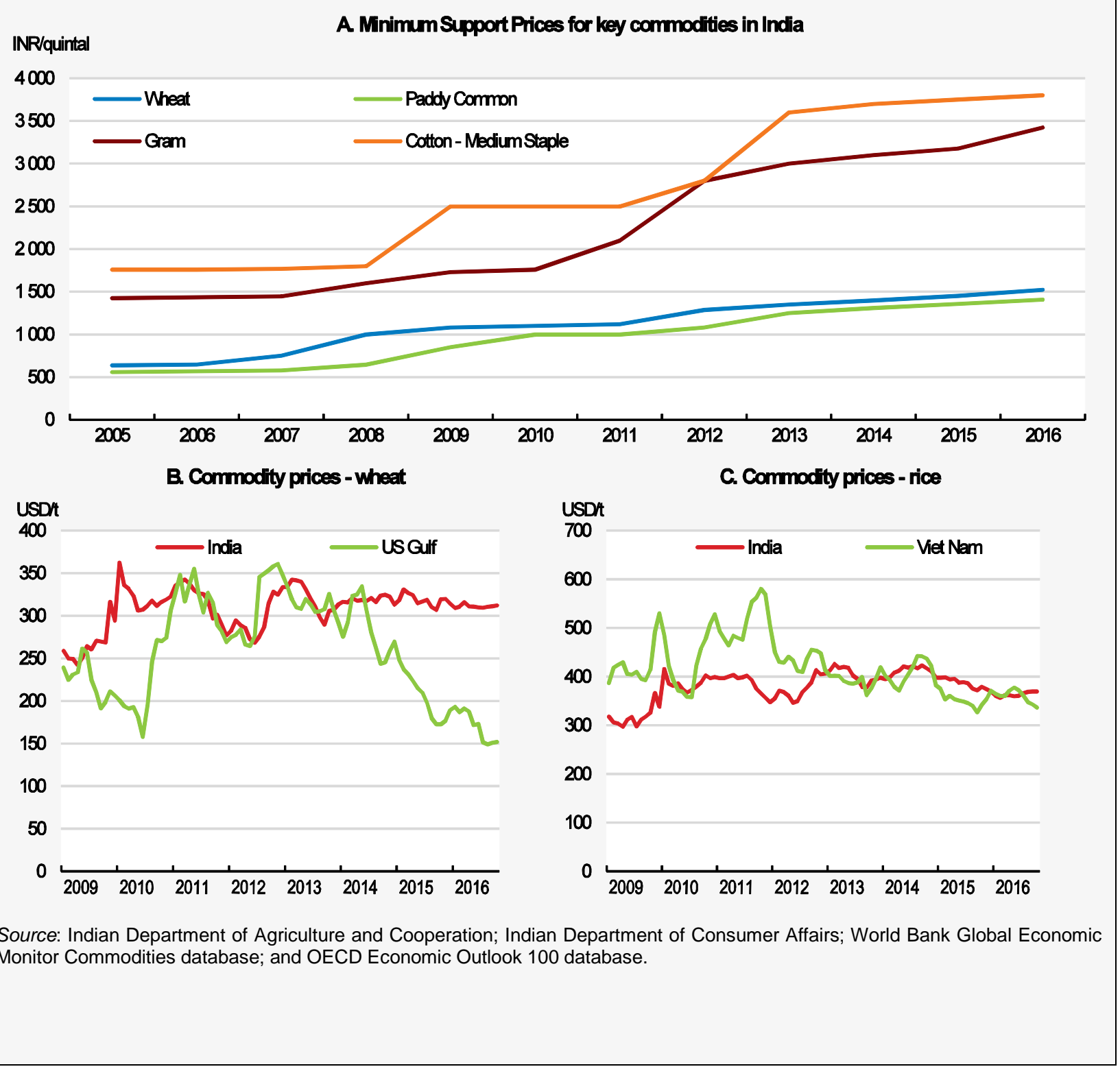


At the state level, subsidisation of electricity for famers is nearly universal. As an example, Andra Pradesh provides free electricity to farmers during off-peak hours to help activities like irrigation. Subsidised or free electricity help low-income farmers to pump water that they could not otherwise afford. Chatterjee (2015), however, finds that crop yields were unaffected by the policy, even though farmers tended to use more electricity-intensive irrigation methods.

Low power tariffs, combined with the provision of minimum support prices for some water-intensive crops, have led to unrestrained exploitation of ground water. Several reports suggest that actual benefits for farmers are very limited (OECD, 2015a; Kochhar et al., 2015), ultimately penalising agricultural productivity. Electricity subsidies should thus be reconsidered. To protect the income of the rural poor, they could be replaced by direct and targeted income support. The government should also support alternative irrigation methods, e.g. drip irrigation, which reduce the consumption of water, electricity and fertilisers, e.g. leveraging on the Rural Employment Programme as well as dedicated training and loan programmes. To promote efficient irrigation practices, the government started to implement the Pradhan Mantri Krishi Sinchayee Yojana (PMKSY), which aims at providing end-to-end solutions in the irrigation supply chain, including water sources, distribution network and farm level applications.

The small size of farms is a key structural barrier to productivity gains as it limits the scope for mechanisation and economies of scale. Of 138 million agriculture landholders, 67\% are marginal farmers (having land of less than 1 hectare) with an average of 0.39 hectare (RBI, 2015). The income of the majority of agricultural households is thus very low. Small farmers tended to be disproportionally indebted to money lenders and other non-institutional lenders, with little money left for investment in machinery and equipment (Table 1). The fragmentation of land holdings continues (OECD-FAO, 2014), partly reflecting inheritance practices, while the lack of well-established land records hampers the transfer and consolidation of land holdings. The National Land Records Modernisation Programme, including the digitisation of land records, should thus proceed more rapidly, following the lead of some states, including Andhra Pradesh (Gulati and Banerjee, 2015; RBI, 2015).

Table 1. Agricultural households: size of land holdings, income, investment and indebtedness

(FY 2012/2013)

\begin{tabular}{|c|c|c|c|c|c|c|c|}
\hline \multirow[b]{2}{*}{$\begin{array}{c}\text { Size of land } \\
\text { possessed } \\
\text { (hectares) }\end{array}$} & \multirow[b]{2}{*}{$\begin{array}{c}\text { Share of } \\
\text { agricultural } \\
\text { households } \\
\%\end{array}$} & \multirow[b]{2}{*}{$\begin{array}{c}\text { Average } \\
\text { monthly } \\
\text { income } \\
\text { INR }\end{array}$} & \multirow[b]{2}{*}{$\begin{array}{c}\text { Average } \\
\text { monthly } \\
\text { consumption } \\
\text { INR }\end{array}$} & \multicolumn{2}{|c|}{$\begin{array}{c}\text { Expenditure on productive farm } \\
\text { assets }\end{array}$} & \multicolumn{2}{|c|}{ Outstanding loans } \\
\hline & & & & $\begin{array}{c}\text { Average } \\
\text { monthly } \\
\text { expenditure } \\
\text { INR }\end{array}$ & $\begin{array}{c}\text { Share of } \\
\text { machinery and } \\
\text { equipment } \\
\%\end{array}$ & $\begin{array}{c}\text { Average } \\
\text { INR }\end{array}$ & $\begin{array}{c}\text { Share from non- } \\
\text { institutional } \\
\text { sources }^{1} \\
\%\end{array}$ \\
\hline$<0.01$ & 2.6 & 4561 & 5108 & 281 & 7.1 & 311 & 85.0 \\
\hline $0.01-0.40$ & 31.9 & 4152 & 5401 & 287 & 16.0 & 239 & 53.0 \\
\hline $0.41-1.00$ & 34.9 & 5247 & 6020 & 837 & 44.3 & 354 & 46.8 \\
\hline $1.01-2.00$ & 17.1 & 7348 & 6457 & 1741 & 17.4 & 548 & 35.1 \\
\hline $2.01-4.00$ & 9.4 & 10730 & 7786 & 1667 & 47.6 & 949 & 32.5 \\
\hline $4.01-10.00$ & 3.7 & 19637 & 10104 & 2805 & 57.9 & 1827 & 28.5 \\
\hline $10.00+$ & 0.4 & 41388 & 14447 & 9568 & 46.6 & 2903 & 21.0 \\
\hline \multicolumn{2}{|c|}{ Weighted average } & 6426 & 6223 & 1013 & 35.2 & 470 & 40.2 \\
\hline
\end{tabular}

1. Includes loans from employer/ landlord, agricultural/ professional money lender, shop keeper/ trader, relatives/ friends and others.

Source: NSS Report No.576: Income, Productive Assets and Indebtedness of Agricultural Households in India. 
Regulation and fragmentation of agricultural markets weigh on farmers' income and ability to invest and become more productive. The Agricultural Produce Market Committee (APMC) Act enacted by state governments provides that first sale in some commodities (cereals, pulse, edible oilseeds, fruits and vegetables, chicken, etc.) can only be conducted under the aegis of the APMC through agents licensed by the APMC. This involves various fees and charges (including a market fee for buyers and a licensing fee for agents which mediate between buyers and farmers), amounting to up to 15\% of the Minimum Support Price set by the government in the case of wheat (Government of India, 2015). Such an approach results in highly fragmented markets for agricultural products, with large price differences, as well as in a significant wedge between retail prices and farmer payments.

The central government developed a model APMC Act in 2003 which provided farmers more freedom to access the market and tried to convince the states to modify their respective APMC Acts. While some states did, further deregulating agricultural markets is needed to increase farmers' income. More investment is also needed to meet transport and storage needs. Deregulating foreign direct investment (FDI) in retail trade would help attract FDI and complement domestic investment. With the objective to reform the agriculture marketing system, a National Agriculture Market (e-NAM) portal has been launched which provides a pan-India electronic trading platform. NAM seeks to network the existing APMCs and other market yards to create an unified national market for agri-commodities. In February 2017, 250 markets from 10 states had been integrated with the new platform.

\section{Shifting resources to high productivity sectors, in particular organised manufacturing}

The reallocation of resources from low to high productivity sectors, typically from agriculture to industry and services, and from the unorganised to the organised sector, should be a key engine for economic growth. Based on an empirical analysis of 16 Indian states over the 2000-06 period, Cortuk and Singh (2015) found that changes in the activity mix cause growth, and not the reverse. Some service sectors, in particular financial and IT activities, have performed well in terms of value added creation and exports. They are highly skill-intensive and cannot create sufficient jobs to match the supply of labour. Manufacturing has to take the lead. Amirapu and Subramanian (2015), however, revealed that in several states, including Gujarat and Maharashtra, resources (jobs in particular) have mostly shifted from agriculture to the unorganised manufacturing sector, itself characterised by relatively low productivity and poor work conditions (Box 3). The reallocation of resources has thus contributed little to boost growth and quality job creation.

Policy has a role to play in supporting productivity growth and the reallocation of resources to the organised manufacturing sector. The 2014 OECD Economic Survey of India showed that the manufacturing sector contributed little to income and job creation as it was suffering most from structural bottlenecks, including frequent power outages, below par transport infrastructure, complex administrative requirements, as well as high taxation and stringent labour regulations. The central government has recently reduced barriers to FDI, made it easier to comply with regulations, reformed the bankruptcy laws, supported investment in infrastructure sectors and put back on track several projects, in particular roads. However, more needs to be done to unlock the potential of the organised sector as suggested by both the 2013 version of the OECD PMR indicators and the 2017 edition of the World Bank Ease of Doing Business index: by international comparison India still struggles with administrative rules for starting a business, dealing with construction permits, paying taxes and getting credit. 


\section{Box 3. Organised versus unorganised manufacturing sectors: definition and contribution to job and value} added creation

The unorganised sector consists of all unincorporated private enterprises owned by individuals or households engaged in the sale and production of goods and services operated on a proprietary or partnership basis and with less than ten workers (or twenty if not using electricity).

The organised sector consists of all public sector enterprises and all private sector enterprises with more than 10 workers (more than 20 if not using electricity).

Although the unorganised manufacturing sector accounts for the bulk of total manufacturing factories and jobs, it contributes only little to the value added of the manufacturing sector (Figure 9). Productivity in the unorganised manufacturing sector is almost 20 times lower than in the organised sector. Less than $1 \%$ of the workers employed in the unorganised manufacturing sectors are entitled to social security benefits, compared with $70 \%$ in the organised manufacturing sector (Mehrotra et al., 2014).

\section{Figure 9 Firms, employment, value added and productivity in organised and unorganised manufacturing}

\section{A. The importance and performance of the unorganised and organised sector, 2010-11}

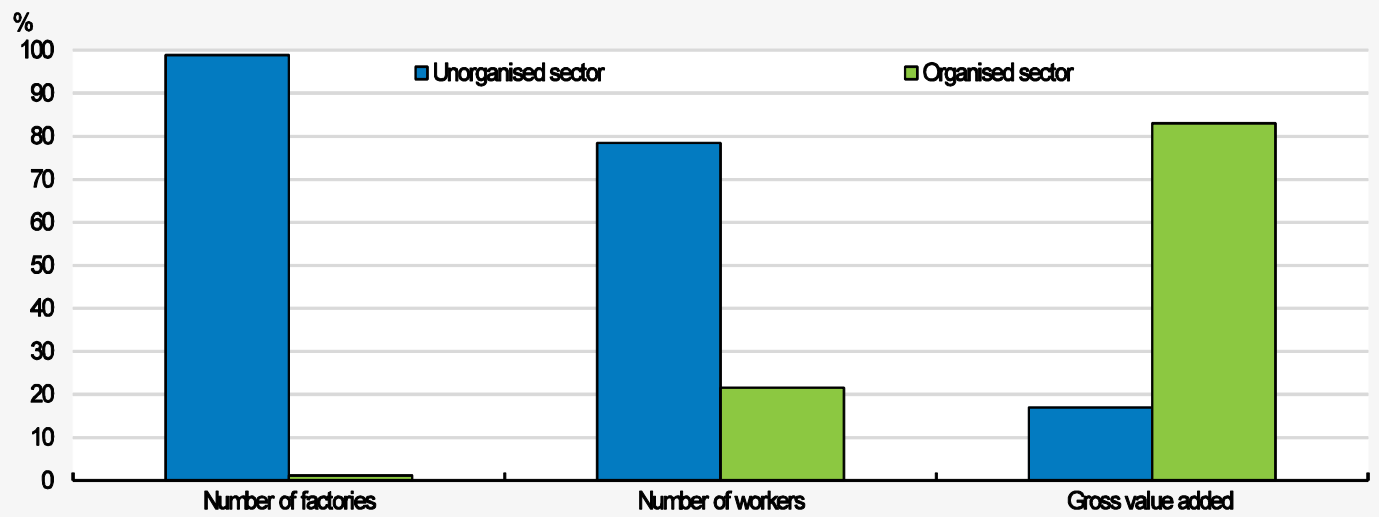

Thousands of rupees

B. Labour productivity', 2010-11

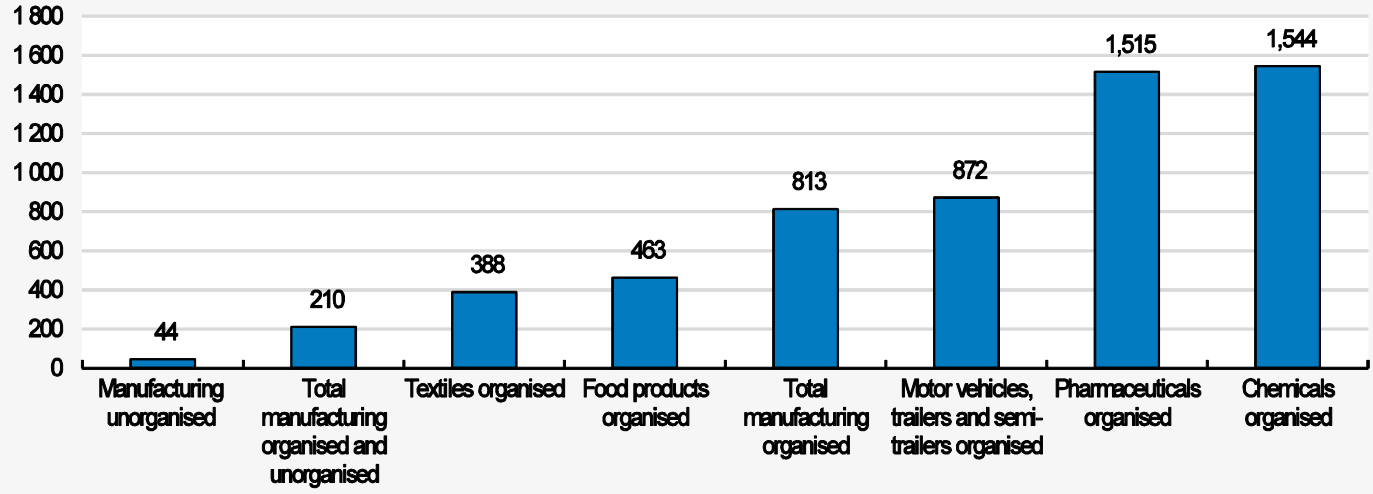

1. Productivity is computed as gross value added per worker.

Source: ASI 2010-2011, NSS 67th round. 


\section{Getting the most out of federalism}

Indian states have an important role to play in easing the severity of structural bottlenecks. The Constitution assigns responsibilities, with some exclusively held by the central government ("central list"), some under the exclusive purview of the states ("state list") and some are the combined responsibility of both the central and state governments ("concurrent list"). Agriculture, public health, water supply, urban development and various aspects of economic development are in the state list while education and the environment are in the concurrent list (Rao, 2014). States have some autonomy in setting taxes and enacting labour and product market regulations (e.g. electricity prices and entry conditions). Overall, states' autonomy in setting taxes and spending programmes are relatively high compared with 13 other federations (Figure 10). The efficiency of their administration, however, differs. Kato and Sato (2014) show that the degree of corruption, as measured by the official number of cases related to violation of anticorruption laws varies across states, with a significant negative impact on labour and total factor productivity in the organised sector.

Figure 10 Tax and spending autonomy of the states: India compared with 13 other federations

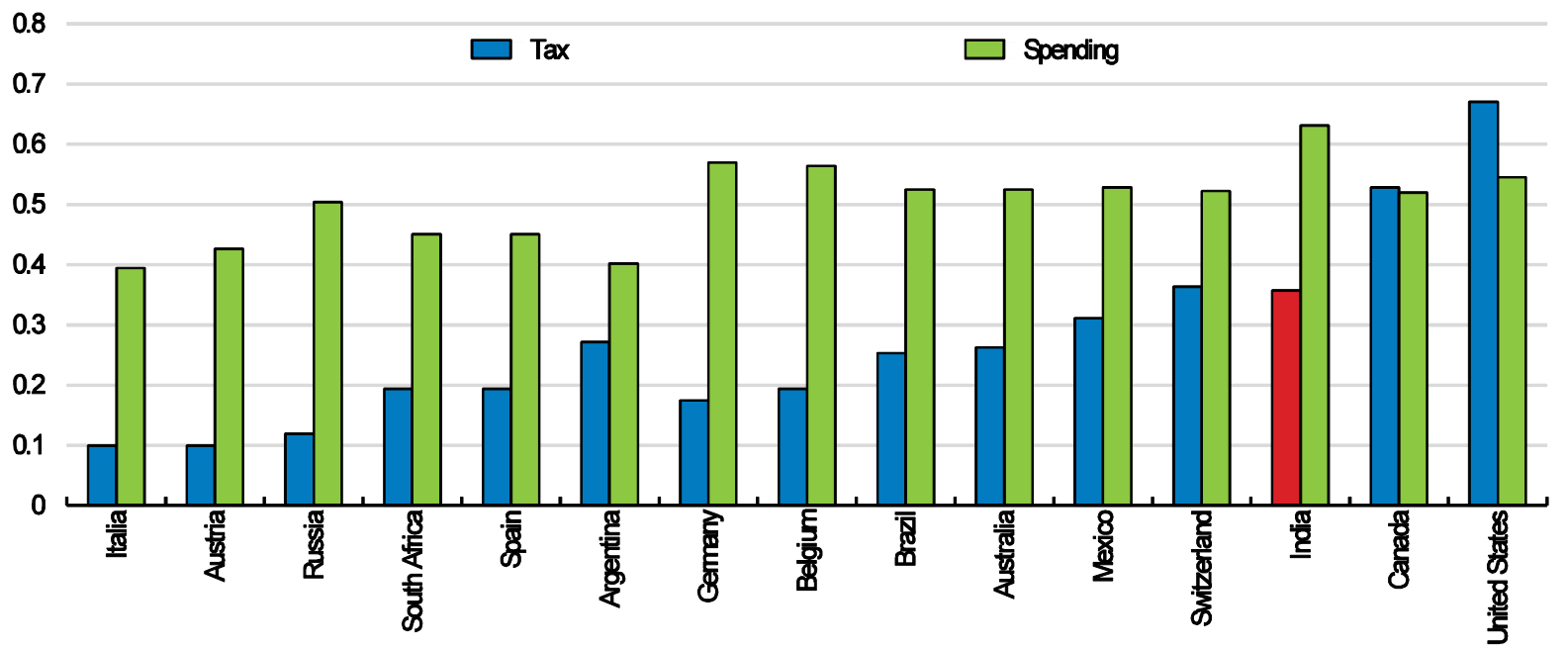

Note: The autonomy indicators capture the assignment of fiscal power across government levels and the extent to which sub-federal governments can conduct policy in the area of taxation and spending. High levels of the indicators are associated with a high level of fiscal autonomy.

Source: OECD Fiscal Network database.

Recent measures have given more financial autonomy to the states and strengthened incentives to pass reforms. The government is promoting a new federalism paradigm - a cooperative and competitive federalism - with less conditional grants from the central government together with more sharing of experience and benchmarking across states (Box 4). This new approach could allow poorer states to move fast and start a virtuous cycle whereby they reform, attract more investment, benefit from an improvement in income and well-being, with higher revenues allowing more investment in physical and social infrastructure. Some states have already taken remarkable initiatives to improve the ease of doing business and better respond to the citizens' needs. Rajasthan is a case in point (Box 5). The Australian experience shows that strengthening arrangements between states to share best practices or collaborate on common issues (for example, regulatory standards or infrastructure) can enhance productivity and wellbeing. 


\section{Box 4. The move to a more co-operative and competitive federalism framework}

\section{Giving more fiscal autonomy to the states by replacing conditional grants by more tax-sharing}

Following the recommendations by the $14^{\text {th }}$ Finance Commission, the government increased the states' fiscal autonomy, by raising their share of the so-called "divisible tax pool" (i.e. all central government taxes excluding surcharges and earmarked taxes) from $32 \%$ to $42 \%$ and by making central government transfers based on more objective criteria, as of FY 2015-16. Government transfers have also been made more progressive as fiscal capacity (defined as the ratio of a state's own revenue to total current expenditure) was given more weight. The budget for some conditional grants, known as "plan transfers" or Central Assistance to States, has been reduced concomitantly. Overall, central government transfers have remained broadly the same in quantitative terms but have improved in qualitative terms (Reddy, 2015) and are more redistributive.

\section{Moving from a top-down approach to the sharing of experience: NITI Aayog}

To foster states' participation in policy-making, the NITI Aayog replaced the Planning Commission in 2015, which had implemented a top-down approach to fiscal transfers and central government programmes. Chief Ministers of each state are on the board of the NITI Aayog, which now acts as a think-tank and promote the sharing best practices.

\section{Strengthening competitive pressures across states by ranking them on the ease of doing business}

In 2014, the government launched an information system on state regulations and administrative practices, allowing the ranking of states in terms of the ease of doing business with a view to nudge the states into competing with each other for better outcomes, while at the same time sharing best practices \& innovations to help each other - an example of competitive and cooperative federalism. In December 2014, state governments agreed to a 98-point Action Plan on the "Ease of Doing Business", under eight key areas setting up a business; allotment of land and obtaining construction permits; complying with environmental procedures; obtaining access to utilities (electricity, water, sewage); registering and complying with tax procedures; carrying out inspections; enforcing contracts. The evaluation (World Bank, 2015) for the first half of 2015 suggests that $32 \%$ of the proposed reforms have been implemented across the country.

Gujarat scored best on the government scoreboard, reflecting efforts to cut red tape, facilitate land acquisition and provide high quality infrastructure and public goods. Gujarat is one of three states (the others being Madhya Pradesh and West Bengal) with a mandate to issue registrations for value-added tax (VAT) and professional tax in a single day. In many states, the ease of paying consumption taxes (including allowing online payment and return filing of various state taxes, defining timelines for VAT registration) has also improved. Clear timelines have been defined for granting construction permits, changes in land use approvals and electricity connection. Labour regulations have become easier to comply with and more transparent in some states. In particular, self-certification schemes which reduce the number of labour inspections required for registrations, annual return filing and renewal of licences under the various labour acts, have been introduced. States have also increasingly relied on application forms that can be filled out and submitted online, with clear timelines and downloadable certificates.

In 2017, the government announced that states will also be ranked on logistics performance, with the objective of promoting infrastructure in trade and transport. The NITI Aayog also introduced indices to measure incremental annual outcomes in critical social sectors like health, education and water. 


\section{Box 5. Rajasthan: recent policy reforms to promote economic development}

Rajasthan is the largest Indian state with 342 thousands $\mathrm{km}^{2}$, but it is relatively poor as measured by GDP per capita (see Figure 5 above). Agriculture accounts for a rather large share of the state's GDP (27\%) despite a lack of water. It is well endowed with natural resources and is one of the leading producers of minerals such as lead, zinc and gypsum. The population is younger than in the rest of India, with $45 \%$ below age 20 (41\% on average in India). The manufacturing sector accounts for only $9 \%$ of total employment, with the bulk (89\%) in the unorganised sector.

To attract investment and give a boost to employment creation in the organised manufacturing sector, Rajasthan has taken the lead in improving the ease of doing business and strengthening the effectiveness of public administration. It has reformed various labour regulations since 2014, benefitting from Article 254(2) of the Constitution - a rarely used clause through which the president allows state law to override national law. In particular:

- Industrial establishments employing up to 300 workers (up from 100) are now allowed to lay off employees without seeking prior permission of the government (amendment to the 1947 Industrial Dispute Act).

- The 1948 Factories Act, which regulates working time and health conditions at work, now applies to factories with more than 20 (up from 10) workers if they use electricity, and 40 (up from 20) if they do not use electricity.

- Temporary labour is regulated for companies with more than 50 workers, up from 20 , under the 1970 Contract Labour Act.

- Membership of $30 \%$ of the total workforce (up from 15\%) needs to be recorded for a union to obtain recognition - a move that is expected to reduce production losses due to industrial disputes.

- The 1961 Apprenticeship Act was reformed to create larger opportunities of employment for the youth. The State now involves industry representatives more closely in designing training programmes. Training can be outsourced and trainers are better paid.

- Exemptions were introduced to the 1947 Boiler Act. Licenses can be renewed through recognised agencies. Certification can be made by outside bodies.

To improve the ease of doing business, Rajasthan has introduced a Single Window Clearance system. The portal aims to act as a single point of contact for all applications and clearances and provides information to investors on relevant rules, policies and other documents required for engaging in business (World Bank, 2015). Rajasthan has further repealed about 150 outdated laws. Overall, it ranked $6^{\text {th }}$ in the 2015 ease of doing business survey sponsored by the DIPP (World Bank, 2015).

The state further offers financial incentives to manufacturing companies, in the form of tax relief or subsidies, including:

- An investment subsidy amounting to $30 \%$ of the state VAT and Central Sales Tax (CST) for seven years (50\% and up to 10 years for lagging areas);

- An employment creation subsidy amounting to up to $20 \%$ of the VAT and CST for 7 years;

- A $50 \%$ reduction in the electricity duty and land tax for seven years;

- A $50 \%$ reduction in Stamp Duty on the purchase or lease of land; a $100 \%$ exemption from Entry Tax (on the movement of goods from one state to another) to enterprises investing more than INR 7.5 billion;

- A "customised" package for large companies.

Rajasthan also reformed land legislation in 2016. The titling law now provides statutory backing to land records and effectively guarantee land and property ownership. This will create an efficient, transparent and modern land market, provide certainty of tenure and end litigation that often mires development projects. The certified title would provide clear title over a chain of documents, enable the use of land as an asset for accessing credit and improve the ability to trade property rights legally. Rajasthan also passed a Land Pooling Schemes Bill which eases the aggregation of small land holdings and should facilitate the development of infrastructure projects. 


\section{Building up infrastructure and human capital across states}

Physical and social infrastructure is key to promote inclusive regional development. Many initiatives have been taken by the central government to improve electricity connections across and within states (Power for all by 2020), sanitation (Clean India), skills (Skill India) and access to various other public services. Despite recent efforts, infrastructure supply remains poor, both in terms of quantity and quality. Many firms face frequent power outages and transport projects often face long delays, weighing particularly on the performance of the manufacturing sector (OECD, 2014a). Policy factors - in particular difficult land acquisition as well as the lack of environmental and other clearances, continue to play an important role. Access to education has been expanded through investment in school infrastructure and recruitment of teachers. Still, differences across states remain wide for many key inputs, including the density of the road network, electricity connections and education (Figure 11). Policy at the state level plays a role. The IEA (2015), for instance, noted the success of the state of Gujarat in promoting solar power since 2009 and the relatively low population share without access to electricity.

\section{Reforming product and labour market regulations at the state level}

The central government sets trade and foreign investment regulations which are thus uniform across states, although their impact may vary with their industrial specialisation and proximity to foreign markets (Harrison et al., 2011). Many labour and product market regulations are, however, set and implemented at the state level, with significant variations across states. Various studies have shown that differences in the stringency of product and labour market regulations across states are correlated with states' economic performance (Conway and Herd, 2008; Dougherty et al., 2008; Aghion et al., 2008). Kapoor (2014) found that states with less flexible labour market regulations have witnessed slower employment growth in the organised manufacturing sector. The 2007 OECD Economic Survey of India built product market regulation (PMR) indicators for 21 Indian states and concluded that states with more competition-friendly regulation have higher labour productivity, attract more foreign investment and have a larger share of employment in the private formal sector. These indicators have not been updated but the same effects can still be observed: stringent PMRs have impeded the shift of resources to the organised manufacturing sector and stifled productivity growth (Figure 12).

Threshold effects in labour and tax regulations create incentives for firms to stay small while some regulations restrain competitive pressures or lock in resources in firms with low productivity. Productivity in the manufacturing sector is particularly low compared to other emerging economies (OECD, 2014a), partly reflecting the preponderance of very small firms (the so-called "unorganised sector"). Even in the organised sector, firms are relatively small (Figure 13), with much lower employment growth over their life cycle (Hsieh and Klenow, 2014), while larger firms tend to have higher productivity. Hsieh and Klenow (2009) estimated that if India were able to align the efficiency of resource allocation to that observed in the United States, productivity could rise by $40 \%$ to $60 \%$. 
Figure 11 The quality of physical and social infrastructure varies significantly across states

\section{A. Density of the road network, 2014-15}
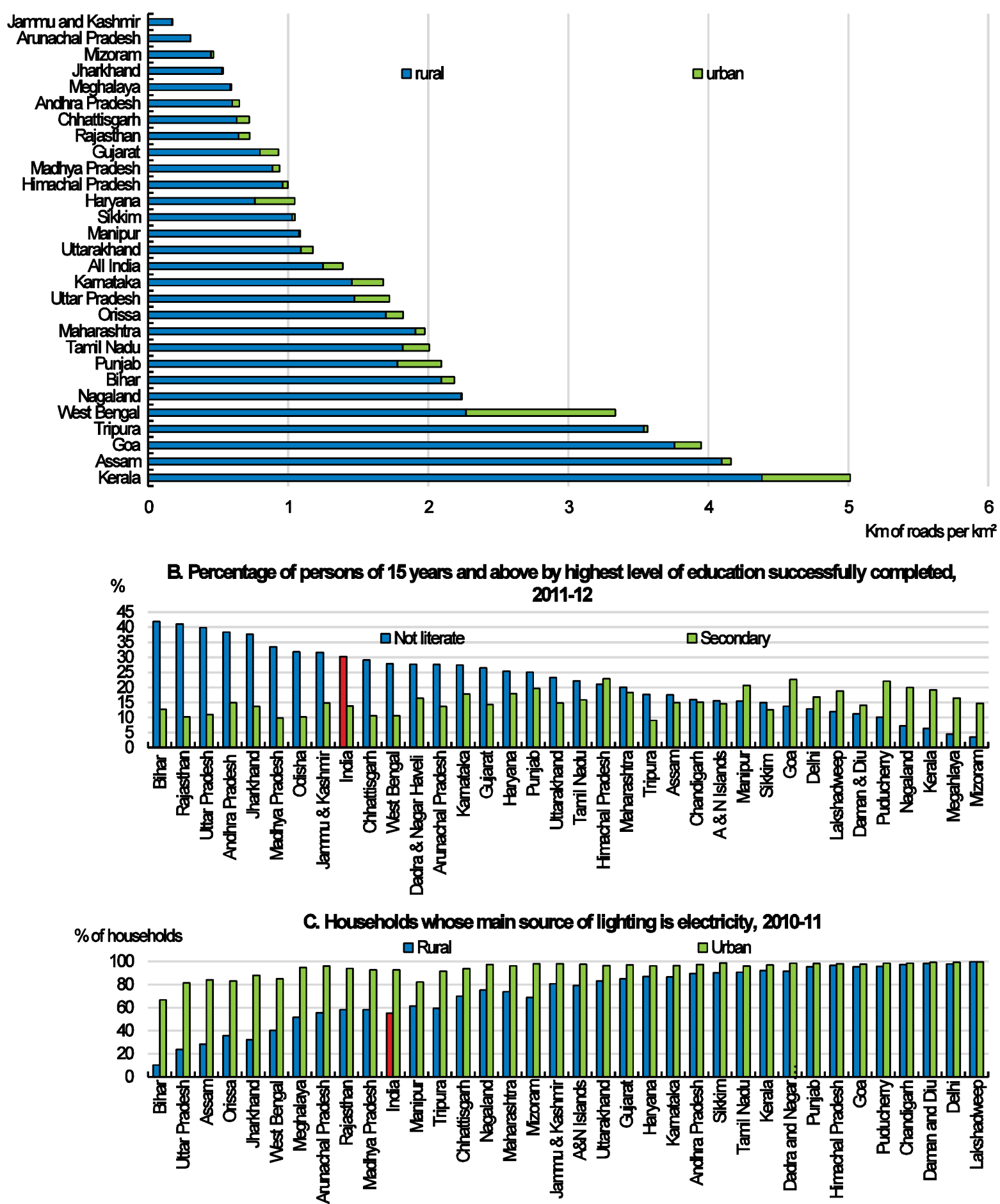

Source: Ministry of Home Affairs; and Ministry of Road Transport and Highways, for panel A; NSS Report No. 566: Status of Education and Vocational Training in India, for panel B; Census of India for panel C. 
Figure 12 Product market indicators and states' performance
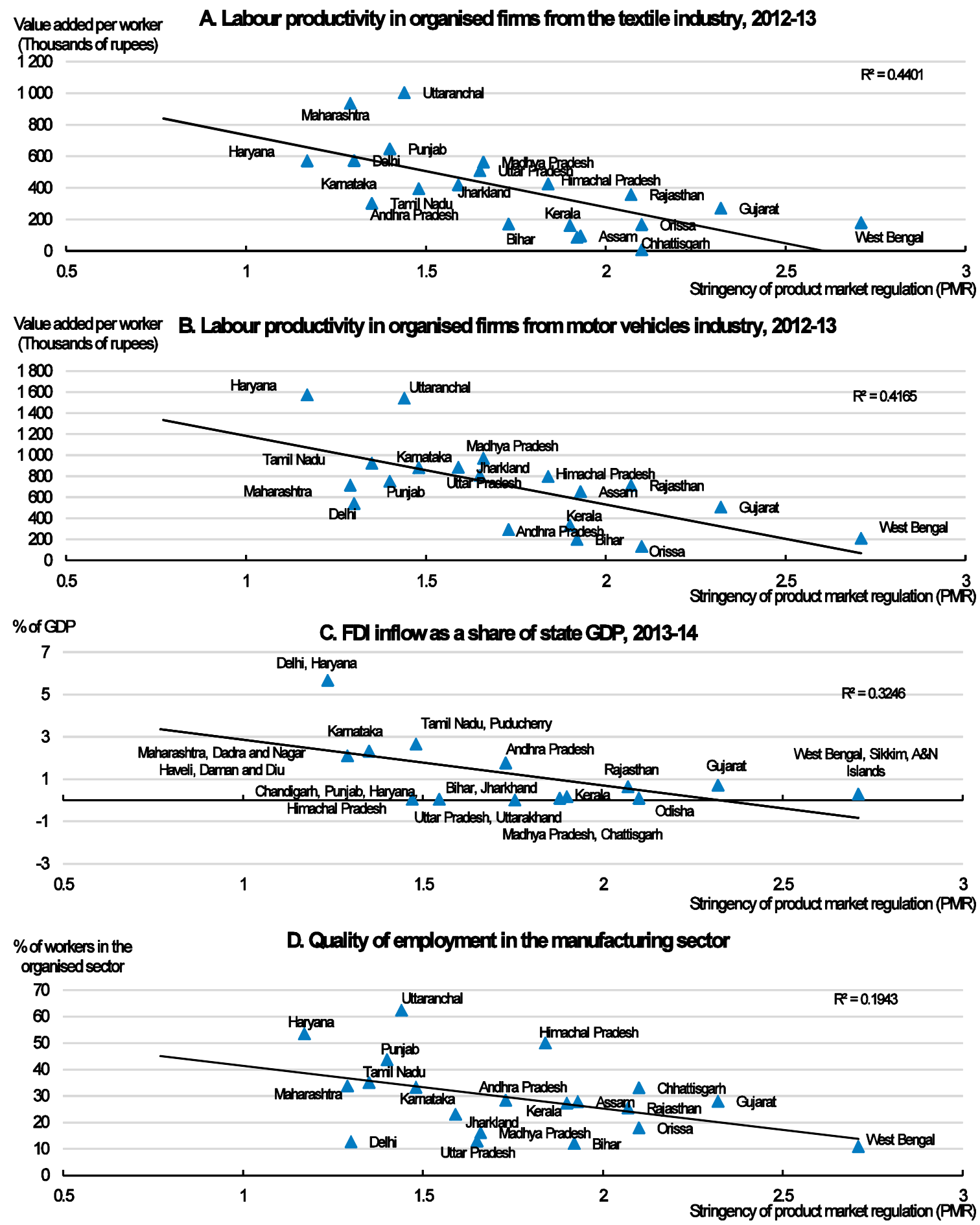

Note: Labour productivity is measured as value added per worker. FDI is measured as cumulative inflows over the period April 2000 to March 2014. PMR indicators shown here cover only two of the three sub-components of the OECD PMR. The sub-component Barriers to Trade and Investment is left out since most of these regulations are set at the national level and are thus similar across states.

Source: Central Statistics Office; OECD Public Sector, Taxation and Market Regulation database; OECD (2007); and Reserve Bank of India. 
Figure 13.Indian firms tend to be small

\section{Percentage of workers by firm size, 2014 or latest year available}

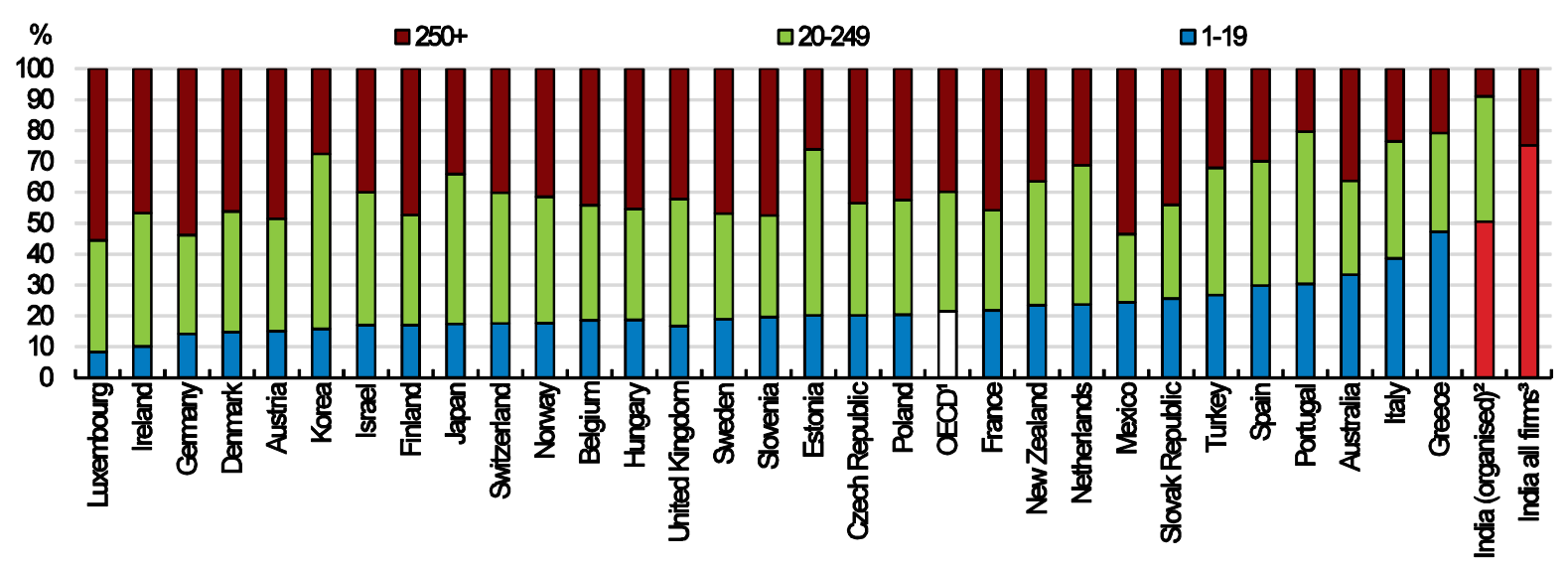

Note: Total employment includes: i) paid employees; ii) employers and self-employed; iii) unpaid family workers.

1. Simple average.

2. For the organised sector in India, the thresholds are 1-19, 20-199 and 200+.

3. For India organised and unorganised sectors together, the thresholds are 1-19 and 20+.

Source: OECD Structural and Demographic Business Statistics database; and Annual Survey of Industries.

Some states have performed better in enabling firms from the organised sector to reach their optimal size. Focusing on labour regulations, Hasan and Jandoc (2012) showed a greater prevalence of larger firms in states with flexible labour regulations - this applies to labour-intensive sectors, while in other sectors firms do not differ much in size across states. Focusing on product market regulations, OECD empirical work (Joumard et al., forthcoming), implementing the approach suggested by Andrews and Cingano (2014) across OECD countries, reveals that:

- Manufacturing firms in the organised sector tend to be much below their efficient size, weighing significantly on productivity. Labour productivity is around $2 \%$ lower than it would be if employment was randomly allocated across firms.

- Some states are more successful in channelling resources to the most productive firms. Jharkhand, Orissa, Bihar, Madhya Pradesh and Delhi are among the best performers (Figure 14).

- Stringent barriers to entrepreneurship have a negative impact on allocative efficiency. Looking separately at the two main sub-components of the barriers to entrepreneurship indicator reveals that regulatory and administrative opacity has a more negative impact on allocative efficiency than administrative burdens on start-ups.

- The degree of public control on manufacturing enterprises, which varies significantly across states, is not associated with differences in allocative efficiency. 
- Reforming product market regulations (PMRs) would make it easier to create better quality jobs and boost income. Potential gains in allocative efficiency, and ultimately productivity, are sizeable. If all states were to lower barriers to entrepreneurship to the level observed in the best performing state (Karnataka), labour productivity in the organised manufacturing sector would increase by almost one half. The gains would be higher in those states where the manufacturing sector is tilted towards industries with a naturally high entry and exit rates and those with initially more stringent PMRs, including West Bengal, Chhattisgarh and Rajasthan.

Overall, the empirical analysis suggests that recent efforts to simplify regulations and improve the ease of doing business in the context of the Make in India initiative will have large positive impacts on productivity in the medium term. They should also help firms to create jobs in the organised sector. They should be pursued with vigour.

Figure 14 Some states do better than others in allocating resources across firms from the organised sector

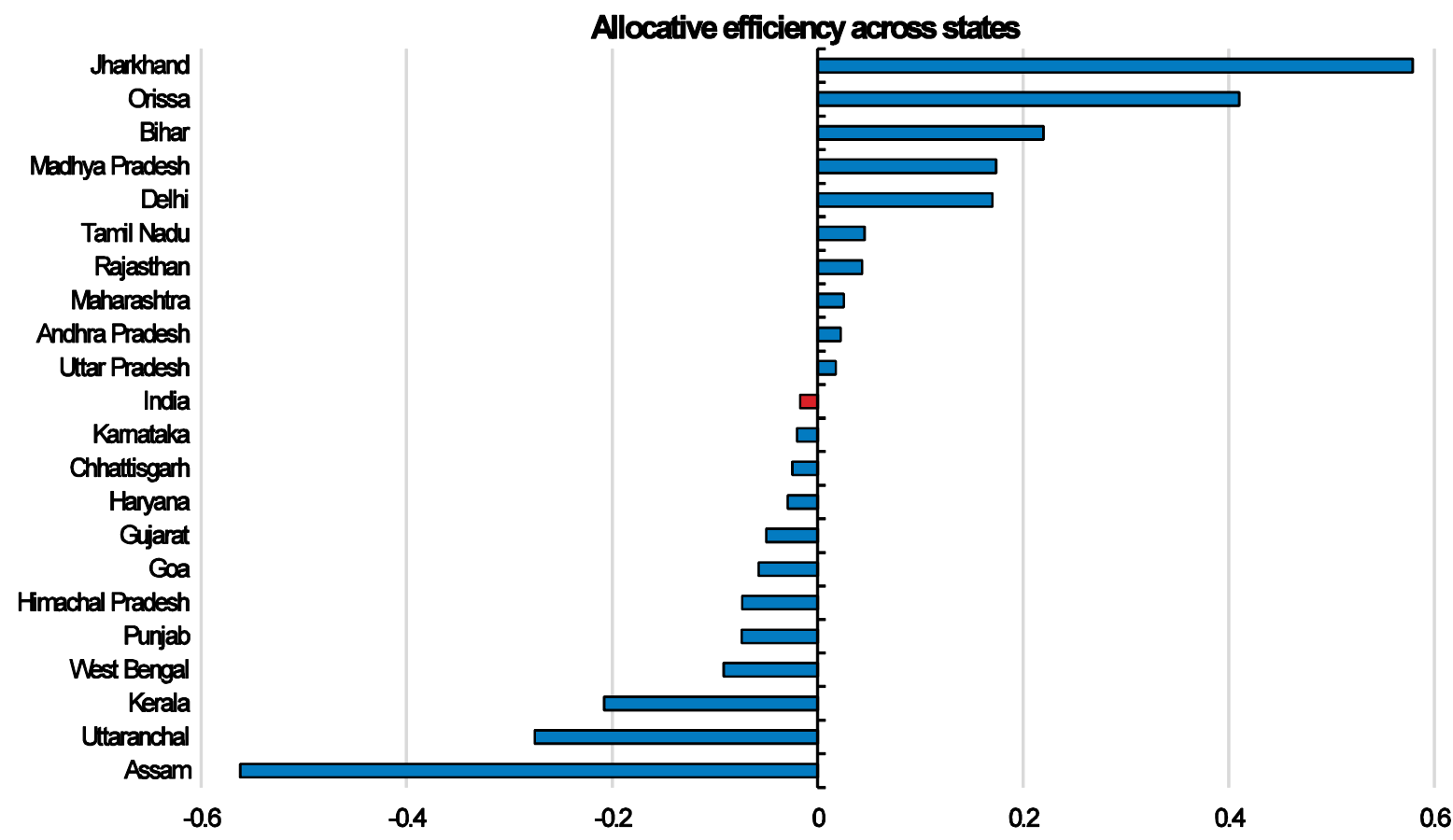

Note: Allocative efficiency indices are obtained as the within-industry covariance between firm size and firm labour productivity (see technical background paper). The state-level indexes are obtained by computing a weighted average of the state-industry indexes, using industry labour share as weights. Positive values indicate that the actual allocation of employment boosts labour productivity compared to the situation where employment is randomly allocated across firms.

Source: OECD calculation, see Joumard et al. (forthcoming). 


\section{Making the most out of the urbanisation process}

\section{The urbanisation process will accelerate}

The urban population has increased rapidly and this trend is set to accelerate. Migration from rural to urban areas has so far been relatively slow compared to China and Indonesia (Figure 15.A), partly reflecting limited job creation in cities, policies to support farmers' income and the rural public employment programme (Imbert and Papp, 2014; Ravi et al., 2012). The share of the rural population, at $69 \%$ of the total population according to the Census, remains very high by international standards. However, the number of workers engaged in non-agricultural activities who cross the rural-urban boundary everyday has increased rapidly (Sharma and Chandrasekhar, 2014). Rural/urban migration pressures are intensifying as the large gap in income and access to core public services between urban and rural areas acts as an important magnet: about half of the farmers are unhappy with their economic conditions and more than two thirds believe that life in cities would be better than in villages (CSDS, 2014). Coupled with population growth, this will make the increase in the urban population one of the fastest in the world in the coming decades (Figure 15.B).

Figure 15 The urbanisation process will accelerate

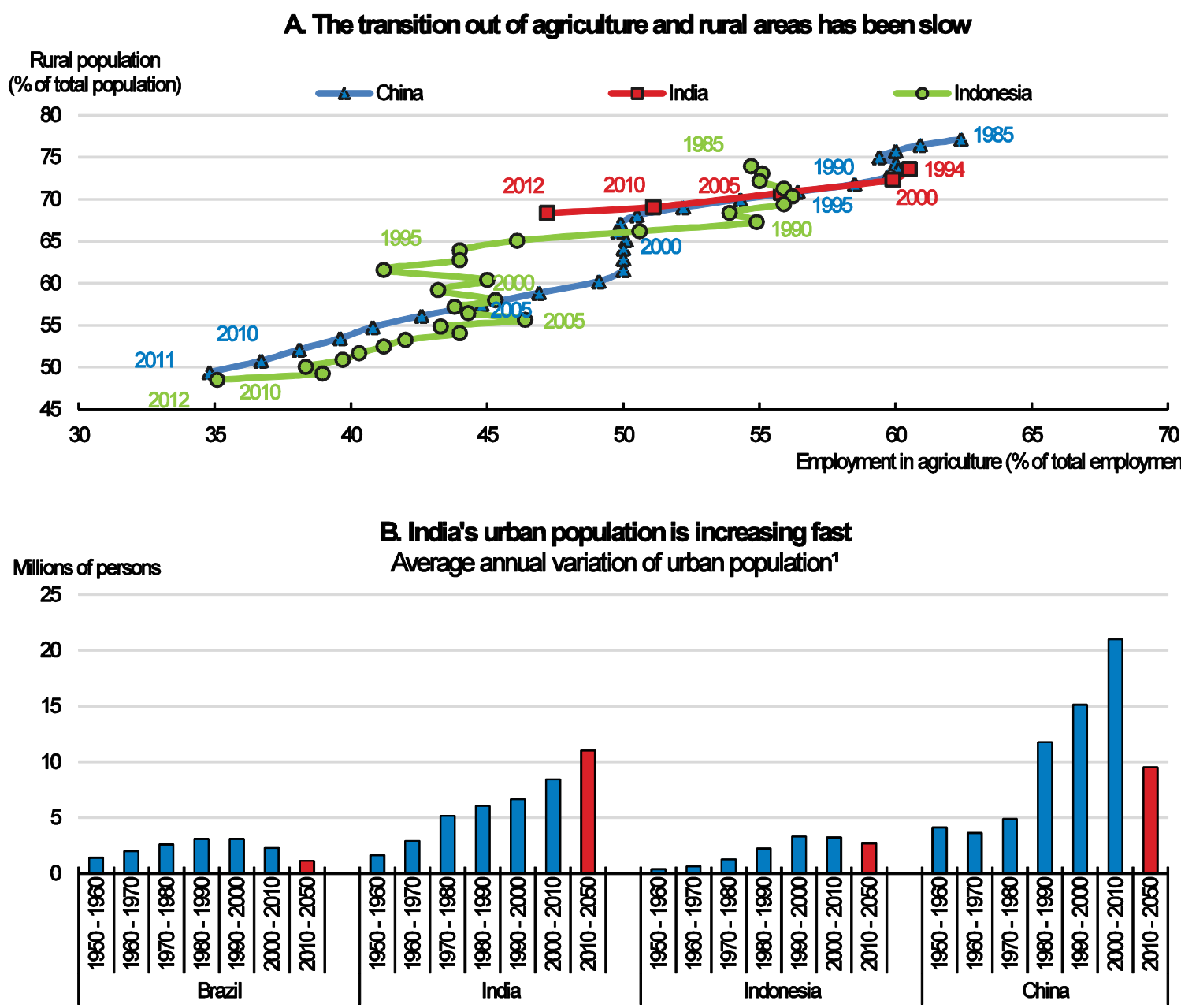

1. Forecasted data are shown in red.

Source: World Bank, for panel A; and United Nations, Department of Economic and Social Affairs, Population Division (2014), for panel B. 


\section{Urbanisation can spur productivity and better respond to citizens' needs}

International evidence suggests that urbanisation can boost economic growth, job creation and the well-being of residents. Metropolitan areas and dynamic medium-sized cities have enormous potential for job creation and innovation, as they are the hubs and gateways in global trade and transport networks (OECD, 2015b). In many OECD countries, labour productivity and wages increase with city size, even after controlling for worker attributes such as the education level (OECD, 2014b). This reflects agglomeration economies, i.e. the concentration of firms and workers in space which makes them more productive thanks to technological spillovers; better opportunities to share intermediate inputs; access to a larger number and wider variety of skilled workers; and access to a larger market which make it possible to exploit scale economies. Urban citizens and firms may also benefit from the availability of amenities and public goods that are only economically viable when provided on a large scale. Recent OECD studies suggest that for each doubling in population size, the productivity level of a city increases by $2 \%$ to $5 \%$.

The potential productivity and well-being gains associated with urbanisation have not been fully exploited in India. Job creation has taken place in urban areas and most of the jobs created in cities are salaried jobs, often offering better conditions than self-employed and casual work (Figure 16.A\&B). In contrast, rural areas have lost jobs, despite rising employment in the construction sector, likely reflecting the implementation of the rural employment programme. Wages in the organised sector are also significantly higher in urban than in rural areas (Figure 16.C). However, a striking feature for India is that productivity declines with city size (Figure 16.D), suggesting that congestion costs quickly exceed agglomeration benefits. This partly reflects an urbanisation process dominated by urban sprawl more than by an increase in urban density, with new urban areas often lacking basic infrastructure and public services such as water provision and sanitation, water draining systems in case of floods, and public transport (World Bank, 2013).

\section{Meeting infrastructure needs and addressing air pollution in urban areas}

The extent to which cities realise their productivity potential and improve the quality of life of their residents largely depends on the quality of their physical and social infrastructure. Neither urban infrastructure nor the level of urban public services is adequate to cater for current needs, let alone to meet growing demands (Rao and Bird, 2010). Housing is a key issue, with 17\% of urban households living in slums on average and up to $41 \%$ in Mumbai according to the latest Census. Differences across states are large: in Kerala less than $2 \%$ of urban households live in slums, compared with more than a third in Andhra Pradesh. Access to water provision and improved sanitation facilities in cities is also low compared with the other BRIICS countries (Figure 17.A). There is not a single city which supplies water 24 hours a day, which can be drunk straight from the tap without health concerns (Biswas and Tortajada, 2016). When available, public transportation is often slow and crowded while individuals with private vehicles are stuck in traffic jams.

Local air pollution has risen fast with urbanisation and, as measured by the level of fine particulates $\left(\mathrm{PM}_{2.5}\right)$, is now very high, with significant adverse health effects. Fine particulates create irreversible lung damages and increase the risk for urban citizens to suffer from stroke, heart disease, lung cancer and chronic and acute respiratory diseases, including asthma. Delhi was the most polluted city in the world in 2013 according to WHO data, with a yearly mean for PM $_{2.5}$ more than 15 times the WHO's air quality guideline. Since then, several measures have led to improvement in air quality. The Delhi government and the Supreme Court directed restrictions in circulation for private vehicles in 2016, with odd and even registration numbers allowed on roads on alternate days. They have also doubled the entry tax of trucks into the city and banned pre-2005 trucks as well as 10-years old commercial vehicles powered by diesel to enter the city. They ordered to curb the burning of waste in the city. Air pollution in Delhi was in 2016 
lower than in 2014 and some smaller Indian cities surpassed Delhi on $\mathrm{PM}_{2.5}$ (Gwalior, Allahabad, Patna and Raipur). Among the 20 most polluted cities in the word stand 10 Indian cities (Figure 17.B).

Figure 16 Potential urbanisation gains are not fully exploited

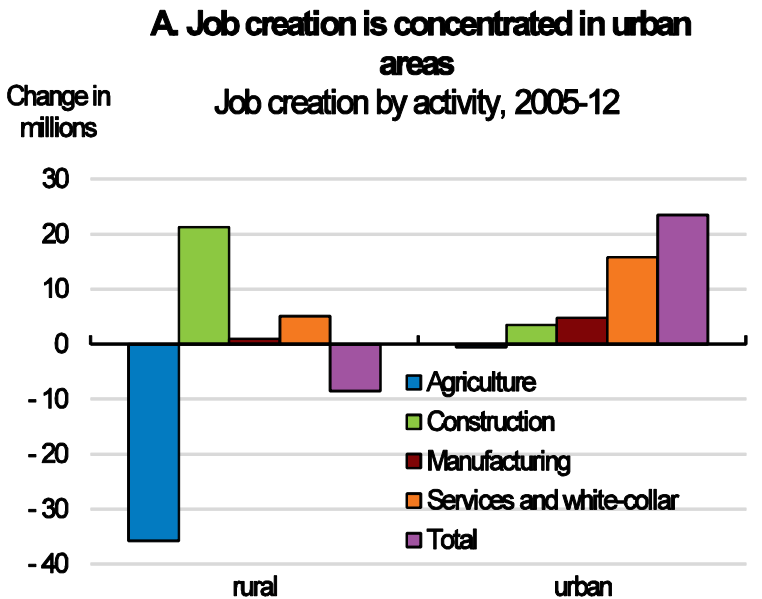

C. Wages are higher in urban areas Average wage and salary', FY 2011-12

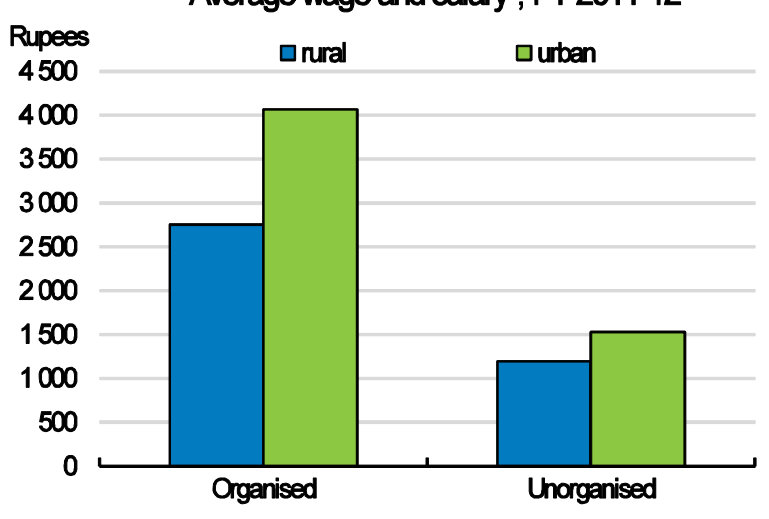

B. Salaried work accounts for the bulk of job creation in urban areas Change in Job creation by status, $2005-12$
millions

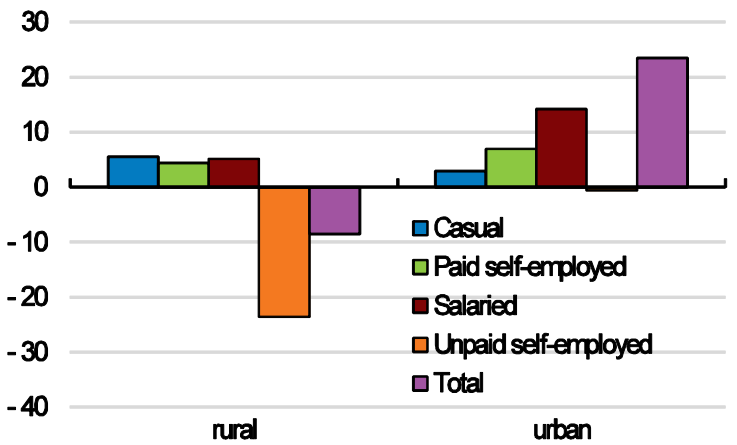

\section{Productivity fails to increase in larger} cities $^{2}$

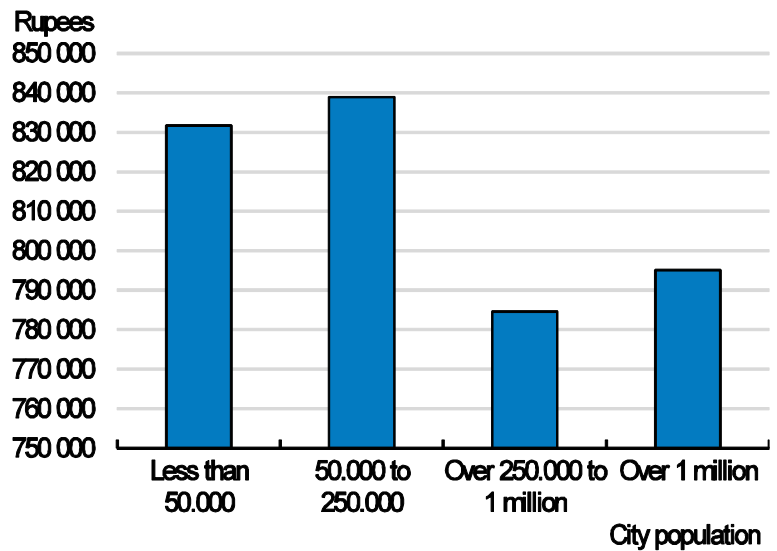

1. Calculated using total wage and salary earnings of all individuals who, during the reference period, worked as a regular wage or salaried employee.

2. Median value added per worker in the organised manufacturing sector.

Source: NSSO, Employment and unemployment survey, rounds No. 61 and 68, for panel A and B; NSSO, Employment and unemployment survey, round No. 68, for panel C; World Bank Enterprise survey 2014, for panel D. 
Figure 17 Urbanisation challenges: infrastructure shortages and local air pollution

A Infrastructure lags: the case of sanitation

Share of urban population using improved sanitation facilities ${ }^{1}$, year 2015

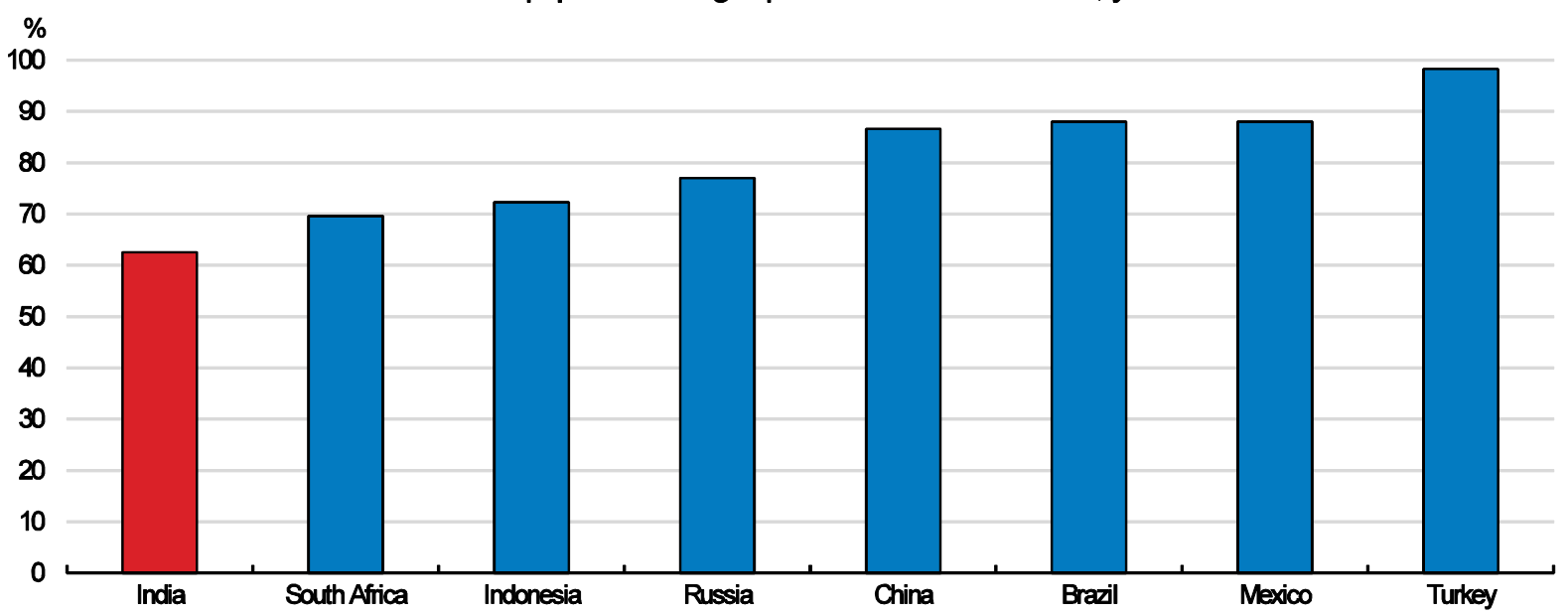

B. Air quality in Indian cities'2, 2014 or latest year available

$\mu \mathrm{g} / \mathrm{m}^{3} \quad$ Average annual PMR.5 concentration in selected cities ${ }^{3}$

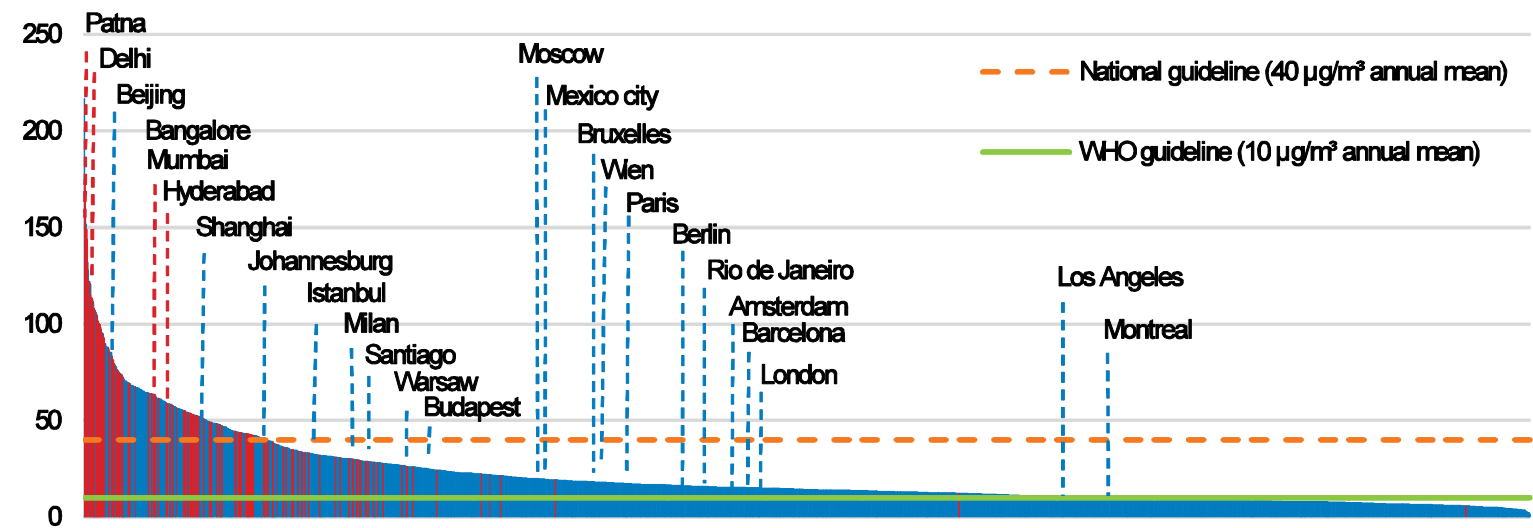

1. An improved sanitation facility hygienically separates human excreta from human contact.

2. Indian cities are marked in red. The other selected cities are marked in blue.

3. PM2.5 refers to particulate matter less than 2.5 micrometers in diameter; these fine particles are particularly damaging to health as they can penetrate deep into the lungs when inhaled.

Source: World Health Organisation, Ambient Air Pollution Database, May 2016.

A national strategy is required to mitigate local air pollution. Prospects are worrying: urban transport activity (measured in passenger-km) in India is projected to grow by $623 \%$ between 2010 and 2050 (International Transport Forum, 2015). This would result in an increase by over $280 \%$ of both NOx and fine particulate $\left(\mathrm{PM}_{2.5}\right)$ emissions and an even larger increase in premature mortality from $\mathrm{PM}_{2.5}$. To mitigate these risks, a national air quality strategy should be implemented, combining: $i$ ) strong priority given to high-quality (reliable and rapid) public transport combined with land-use planning aimed at containing urban sprawl and air pollution - metro trains are being taken up in many cities; ii) targeted use of economic incentives such as tax on gasoline and diesel, road tolls and parking prices; iii) emission standards for vehicles to replace interim measures, such as banning the use of (highly polluting) three wheelers as already implemented in some Indian cities (e.g. Mumbai). 
Upgrading urban infrastructure would require improving urban governance and increasing local governments' financial resources. The Constitution formally recognised local authorities in 1992. However, the sharing of responsibilities between states and local governments often remains unclear, with frequent overlaps. Some municipalities are highly fragmented, with a superposition of wards, municipal corporations, towns, non-municipal urban areas and villages. Decision-making is often dysfunctional because it is split between elected and the career civil servants and neither can be held accountable (Morris, 2010). Reliable information on local government finances and quality of services is lacking (Report of the $14^{\text {th }}$ Finance Commission). States can decide to abolish local taxes on immovable properties, and some did so (Rao and Bird, 2010). They can also reduce the rental value, which serves as the base for the recurrent tax on immovable property in most cases, or to introduce tax concessions.

Some Indian cities were among the pioneers of urban planning (Box 6). However, stringent land use regulations, including ceilings on floor area that is allowed to be built on an area of land, or very little planning at all in some cities, have resulted in urban sprawl (Glaeser, 2011; Morris, 2010). And long commuting distances are not matched by high quality public transport systems.

\section{Box 6. India has pioneered urban planning: the city of Chandigarh}

The city of Chandigarh is the capital of the states of Punjab and Haryana. Its master plan was prepared in the early 1950 s by Le Corbusier at the request of India's first Prime Minister Nehru. It is still famous for its architecture and urban design (Papillault, 2006) and was considered recently as the cleanest and richest city in India.

Le Corbusier identified four basic functions of a city - living, working, circulation and care of the body and spirit - which were implemented in Chandigarh (Krishnan, 2012). These remain very much aligned with current criteria to make cities an engine of growth and well-being - spatially compact, medium to high density, human centred, tightly linked by a mass transit system, with an emphasis on the provision of essential public services (including education and health care), public green areas, attractive public buildings, low pollution levels, safe walking infrastructure, accessibility to jobs and facilities for social and cultural interaction.

Enhancing urban governance would require better specifying what services municipalities should provide, given the size of its population and reducing fragmentation in decision-making. For metropolitan areas with highly fragmented municipal bodies, giving an organisation a clear focus on metropolitan issues and a broad mandate in terms of policy fields would help ensure that cities function well. This would improve the co-ordination between land use and transport planning. Removing ceilings on floor space indices, or at least raising them substantially, would also contribute to a better use of urban land. It is also vital to streamline the procedures involved in land acquisition and conversion, and to create the institutions needed for a well-functioning land market, particularly with respect to clear title and effective valuation processes. Political accountability could also be improved. In some cities, the mayoral term is short (less than five years) while in others the mayor is not directly elected. To effectively empower municipalities, training programmes for local government officials would help raise administrative capacity.

Local government revenues should be increased. The High Powered Expert Committee set up by the Ministry of Urban Development estimated that meeting urban infrastructure needs would require increasing spending from $0.7 \%$ of GDP in FY 2011-12 to 1.1\% over the next 20 years (ICRIER, 2011). Since then, various flagship programmes have been launched (Box 7). Central government funding has increased and there is scope to attract more private financing. Still, this falls short of the estimated needs, calling for substantial financial participation by the state and local governments. The fiscal federalism literature (Joumard and Kongsrud, 2003; Ahmad et al., 2014) suggests that the tax on immovable property and user charges are the most appropriate financial resources for local governments. In India, revenue from these two sources remains relatively low (Joumard et al., 2017; Rao and Bird, 2010; Rao, 2013). 


\section{Box 7. Recent initiatives to improve urban infrastructure in India}

The Atal Mission for Rejuvenation and Urban Transportation (AMRUT) launched in June 2015 aims at (i) ensuring that every household has access to a tap with assured supply of water and a sewerage connection; (ii) increasing the amenity value of cities by developing greenery and well-maintained open spaces (parks); and (iii) reducing pollution by switching to public transport or constructing facilities for non-motorised transport (e.g. walking and cycling). Central government funds amount to INR 500 billion (about $0.4 \%$ of 2015 GDP) spread over a five year period, to be complemented by state and local governments. It replaces the Jawaharlal Nehru National Urban Renewal Mission (JNNURM) which spent INR 43 billion over a nine-year period. Few of the projects initiated under the JNNURM have, however, been completed (2012 Comptroller and Auditor General report), largely reflecting: i) delays in acquiring land; ii) deficiencies in preparing projects; iii) non-identification of beneficiaries which increased the risk of ineligible beneficiaries getting the benefits. Large differences in completion rates were observed across states, with Gujarat faring best at 55\%. Compared with the JNNURM, the AMRUT provides states with more flexibility in the use of the grants allocated to them, which should speed up project implementation.

In parallel, the government launched in 2015 a programme to develop 100 Smart cities, to be selected through an open and transparent competition process. Each state shortlisted its smart city aspirants in line with scoring criteria and submitted proposals to the central government for evaluation and financial support. A majority of states have included their capitals in the list -- 21 entries are for state capitals or for parts within state capitals. A list of 98 potential smart cities was released in August 2015. Out of the 100 cities, 60 were selected in January 2017 covering 72 million residents, including parts of Delhi, Chennai and Ahmedabad. Each smart city will receive central government assistance. The central government has approved a sum of INR 480 billion $(0.4 \%$ of 2015 GDP) for the project in the next five years to be supplemented by state governments, urban local bodies and the private sector.

In June 2015, the government launched the Housing for all programme. It aims at providing housing for all urban poor by 2022. The estimated costs amount to INR 12-13 trillion (about $9 \%$ of 2015 GDP), of which 3 trillion to be funded by the central government. The scheme will mainly focus on the rehabilitation of slums and the provision of affordable housing to low-income poor through subsidised loans.

Clean India (Swachh Bharat) is a national campaign to eliminate open defecation by 2019 by constructing toilets and to improve solid waste management in cities. A total investment need of INR 620 billion ( $0.5 \%$ of FY 2015 GDP) is envisaged up to 2019 , of which a fourth to be borne by the central government and the rest by states, urban local bodies and the private sector. To finance the campaign, the government introduced a $0.5 \%$ earmarked tax on services. A Cleanliness index ranking cities' performance was released.

Municipal Bonds - The central government provides support to Urban Local Bodies to issue municipal bonds for investment in urban infrastructure under its flagship missions such as Smart Cities Mission (SCM). 
Raising more property tax revenue would require improving clarity in property ownership, up-to-date valuation of properties and more autonomy in setting the base and rates and to enforce the tax. Some cities in India (e.g. Bangalore) and in other emerging countries (Bogota and Baranquilla in Colombia) have introduced a self-assessment system which could be replicated. Property values should also be up-dated frequently. In the absence of relevant information on actual market values, house price, construction price or consumption price indices could be used as an auxiliary measure to up-rate properties in-between reevaluations (OECD, 2015c).

User charges for urban infrastructure should be raised, especially for those services with a characteristic of "private goods", although this should be accompanied with a commitment to improve the quality of services. User charges in most cities are currently set well below operation and maintenance costs, in particular for power and water provision (Pratap, 2015). Relying more on parking fees and road pricing would entail a double dividend, i.e. raising more revenue and reducing private car usage and thus pollution. For core public services, however, some mechanisms would need to be introduced to protect the most vulnerable households (e.g. guaranteeing a reduced price for consumption below a threshold). Municipal bonds for public-private partnership projects in urban local bodies including for services with user charges are envisaged in at least three major cities. 


\section{Recommendations for achieving strong and balanced regional development}

\section{Boosting productivity in the agriculture sector}

- Support farm consolidation to exploit economies of scale and to promote mechanisation by improving clarity of land titles. Digitisation of land rights would further allow better access to credit to fund investment.

- Remove subsidies for fertilisers, electricity and water used by farmers and replace them by a direct income support scheme. Better aligning the price of inputs (e.g. fertilisers, electricity and water) with their true social costs, including pollution and scarcity, would promote a more sustainable use of natural resources.

- Pursue efforts to deregulate and unify markets for agricultural products to support farmers' income.

- Invest more in rural infrastructure, such as roads connecting villages to market towns, crop storage infrastructure and access to sustainable irrigation technologies such as drip irrigation.

\section{Boosting productivity in the manufacturing sector}

- Improve the ease of doing business at the central and state level further by continuing the benchmarking of states and by strengthening the sharing of best practices across states.

- Simplify the bureaucratic procedures of securing regulatory approvals and environmental clearance for infrastructure projects. Define timelines for all stages of granting approvals and rely more on single window clearance mechanisms. Review the timelines within the Land Acquisition Bill to make land acquisition faster.

\section{Making the most out of urbanisation}

- Promote better urban infrastructure by empowering metropolitan bodies, making them accountable, giving them and municipal governments more revenue-raising powers and strengthening administrative capacity.

- Enable local governments to raise more taxes on immovable properties by helping them to assess and up-date the value of properties and by giving them more autonomy to set the base, rate and enforce taxes on immovable properties.

- Raise user charges for urban infrastructure while committing to better services, and securing access of the poor to public services.

- For metropolitan areas with highly fragmented municipal bodies, create an organisation with a clear focus on metropolitan issues to promote better co-ordination between land use, transport planning and other key public services.

- Implement a national air quality strategy combining: i) strong priority given to quality public transport ii) targeted use of economic incentives such as tax on gasoline and diesel, road tolls and parking prices; iii) emission standards for vehicles. 


\section{REFERENCES}

Aghion P., R. Burgess, S. Redding and F. Zilibotti (2008), "The unequal effects of liberalization: evidence from dismantling the license Raj in India”, American Economic review 2008, Vol. 98:4, pp. $1397-1412$ http://www.princeton.edu/ reddings/pubpapers/ABRZ_AER_Sept2008.pdf

Ahluwalia, M. (2000), "State Level Performance Under Economic Reforms in India" (Paper presented at the Centre for Research on Economic Development and Policy Reform Conference on Indian Economic Prospects: Advancing Policy Reform, May 2000; Stanford University) http://planningcommission.nic.in/aboutus/speech/spemsa/msa007.pdf

Ahmad, A., G. Brosio and C. Pöschl (2014), "Local Property Taxation and Benefits in Developing Countries - Overcoming political resistance" LSE Asia research Working Paper 65 http://www.lse.ac.uk/asiaResearchCentre/_files/ARCWP65-AhmadBrosioPoeschl.pdf

Amirapu, A. and A. Subramanian (2015), "Manufacturing or Services? An Indian Illustration of a Development Dilemma", Center for Global Development Working Paper 409, June Papers\Amirapu Subramanian Manufacturing Services 2015.pdf 2015Papers\Amirapu Subramanian Manufacturing Services 2015.pdf

Andrews, D. and F. Cingano (2012), "Public Policy and Resource Allocation: Evidence from Firms in OECD Countries", pp. 253-296, OECD Economics Department Working Papers, No. 996, OECD Publishing, Paris.

DOI: http://dx.doi.org/10.1787/5k9158wpf727-en

Bhagwati, J. and A. Panagariya (2013), Why Growth Matters: How Economic Growth in India Reduced Poverty and the Lessons for other Developing Countries New York : Public Affairs, ISBN: 9781610393737

Biswas, A. and C. Tortajada (2016), "India's looming water crisis", Asian Century Institute Policy Forum, http://www.policyforum.net/indias-looming-water-crisis/

CSDS (2014), "State of Indian Farmers", Lokniti report http://www.lokniti.org/pdf/Farmers_Report_Final.pdf

Chatterjee, S. (2015), “Powering’ Agriculture Andhra Pradesh's Free Electricity Story”, EPW, Vol. L, No 44.Paperslchatterjee 2015 electricity powering Agriculture.pdf

Conway, P. and R. Herd (2008), "Improving Product Market Regulation in India: An International and Cross-State comparison", OECD Economics Department Working Papers, No. 599, OECD

Publishing, Paris.

DOI: http://dx.doi.org/10.1787/243233330374

Cortuk O. and N. Singh (2015) "Analysing the structural change and growth relationship in India: statelevel evidence”, Vol. 50, Issue No 24, June 13, 2015.

Dougherty, S. (2008), "Labour Regulation and Employment Dynamics at the State Level in India", OECD Economics Department Working Papers, No. 624, OECD Publishing, Paris.

DOI: http://dx.doi.org/10.1787/241014565862 
Drèze J. and A. Sen (2013), An Uncertain Glory - India and its Contradictions, Princeton Press.

Glaeser, E. (2011), "Triumph of the City: How Our Greatest Invention Makes Us Richer, Smarter, Greener, Healthier and Happier", Macmillan

Government of India (2015), Economic Survey 2014/15.

Government of India (2016), Economic Survey 2015-16.

Government of India (2014), Key Indicators of Situation of Agricultural Households in India, NSS 70th Round.

Government of India (2013), Report of the Committee for evolving a composite development index of states, http://finmin.nic.in/reports/Report_CompDevState.pdf

Gulati A. and P. Banerjee (2015), "Rationalising Fertiliser Subsidy in India: Key Issues and Policy Options", ICRIER Working Paper No. 307, August. http://icrier.org/pdf/Working_Paper_307.pdf

Harrison A., L. Martin and S. Natara (2011), "Learning versus Stealing -- How Important are Market-Share Reallocations to India's Productivity Growth" Rand Working Paper WR832 http://www.rand.org/content/dam/rand/pubs/working_papers/2011/RAND_WR832.pdf

Hasan, R. and Jandoc, K.R.L. (2012) "Labor Regulations and the Firm Size Distribution in Indian Manufacturing". Columbia Program on Indian Economic Policies, Working Paper No. 2012-3 http://indianeconomy.columbia.edu/sites/default/files/working_papers/wp_2012-3.pdf

Hasan R., D. Mitra, and A. Sundaram (2012) "What explains the high capital intensity of Indian manufacturing?" Indian Growth and Development Review, vol 6, Issue 2. http://www.emeraldinsight.com/journals.htm?articleid=17095402

Hsieh C. and P. Klenow (2009), "Misallocation and manufacturing TFP in China and India" The Quarterly Journal of Economics, Vol. CXXIV, November, Issue 4.

Hsieh C. and P. Klenow (2014), “The Life Cycle of Pants in India and Mexico”, Vol. 129 August 2014 Issue 3, The Quarterly Journal of Economics http://qje.oxfordjournals.org/content/129/3/1035.full.pdf+html

ICRIER (2011), Report on Indian Urban Infrastructure and Services, March 2011, http://icrier.org/pdf/FinalReport-hpec.pdf .

IEA (2015), World Energy Outlook.

Imbert, C. and J. Papp (2014), "Short-term Migration, Rural Workfare Programs and Urban Labor Markets: Evidence from India's Employment Guarantee", Job Market Paper.

International Transport Forum. (2015), ITF Transport Outlook 2015, OECD Publishing, Paris. DOI: http://dx.doi.org/10.1787/9789282107782-en

Joumard, I. and P.M. Kongsrud (2003), "Fiscal Relations across Government Levels", OECD Economics Department Working Papers, No. 375, OECD Publishing, Paris.

DOI: http://dx.doi.org/10.1787/455513871742 
Joumard I. and A. Thomas and H. Morgavi, "Making Income and Property Taxes More Growth-Friendly and Redistributive in India", OECD Economics Department Working Paper No. 1389, OECD Publishing, Paris. DOI: http://dx.doi.org/10.1787/5e542f11-en

Joumard I., H. Bourrousse and H. Morgavi (forthcoming), "The Impact of State Level Regulations on Allocative Efficiency Across Firms in the Indian Organised Manufacturing Sector”.

Kapoor, R. (2014), “Creating Jobs in India's Organised Manufacturing Sector”, ICRIER Working Paper No. 286 http://icrier.org/pdf/Working_Paper_286.pdf

Kato A., and T. Sato (2014), "The Effect of Corruption on the Manufacturing Sector in India", Economics of Governance - Volume 15, Issue 2, May 2014

Kochhar K., C. Pattillo, Y. Sun, N. Suphaphiphat, A. Swiston, R. Tchaidze, B. Clements, S. Fabrizio, V. Flamini, L. Redifer, H. Finger, and an IMF Staff Team (2015), "Is the Glass Half Empty or Half Full? Issues in Managing Water Challenges and Policy Instruments", IMF Staff Discussion Notes No. $15 / 11$

https://www.imf.org/external/pubs/ft/sdn/2015/sdn1511.pdf

Krishnan A. (2012), "Eco-City? Eco-Urbanity?" in Eco-Urbanity: Towards Well-Mannered BuiltEnvironment, Radovic D. ed., Routledge.

Mehrotra S., R. Raman, N. Kumra, N. Kalaiyarasan and D. Röß (2014), Vocational education and training reform in India: business needs in India and lessons to be learned from Germany, Bertelsmann Stiftung.

Mookherjee D. and A. Shorrocks, (1982), "A Decomposition Analysis of the Trend in UK Income Inequality”, Economic Journal, 1982, vol. 92, issue 368, pp. 886-902.

Morris S., (2010), "Issues in Real Estate and Urban Management - A Note”, IIM Ahmedabad, W.P. No. 2010-11-01.

NITI Aayog (2015), "Raising Agriculture Productivity and Making Farming Remunerative for Farmers", occasional paper.

OECD (2014a), OECD Economic Surveys: India 2014, OECD Publishing, Paris.

DOI: http://dx.doi.org/10.1787/eco_surveys-ind-2014-en

OECD(2014b), OECD Regional Outlook 2014: Regions and Cities: Where Policies and People Meet, OECD Publishing, Paris.

DOI: http://dx.doi.org/10.1787/9789264201415-en

OECD (2015a), Drying Wells, Rising Stakes: Towards Sustainable Agricultural Groundwater Use, OECD Studies on Water, OECD Publishing, Paris.

OECD (2015b), The Metropolitan Century: Understanding Urbanisation and its Consequences, OECD Publishing, Paris.

OECD (2015c), "Reforming the Recurrent Tax on Immovable Property: Draft Guiding Principles", COM/CTPA/ECO/GOV(2015)5 
OECD (2013), Economic Policy Reforms 2013: Going for Growth, OECD Publishing, Paris. DOI: http://dx.doi.org/10.1787/growth-2013-en

OECD and FAO (2014), OECD-FAO Agricultural Outlook 2014, OECD Publishing, Paris. DOI: http://dx.doi.org/10.1787/agr_outlook-2014-en

OECD (2010), Health Care Systems: Efficiency and Policy Settings, OECD publishing.

OPHI (2015), Country Briefing India, December 2015.

Papillault R. (2006), Portait de ville - Chandigarh, Cité de l'architecture et du patrimoine.

Pratap K.V., (2015), "Financing of Smart Cities", http://smartcities.gov.in/writereaddata/Financing\%20of\%20Smart\%20Cities.pdf

Rajan R. and A. Subramanian (2006), “The Bangalore Bug”, Financial Times, March.

Rao G.M. and R.M. Bird (2010), "Urban Governance and Finance in India”, NIPFP Working Paper No. 68 http://ideas.repec.org/p/ess/wpaper/id2495.html

Rao G. (2013), "Property Tax System in India: Problems and Prospects of Reform", NIPFP Working Paper No. 114 http://www.nipfp.org.in/media/medialibrary/2013/04/WP_2013_114.pdf

Rao G. (2014), "Fiscal federalism in India", Note prepared for the OECD Fiscal Network, COM/CTPA/ECO/GOV(2014)4/ANN10

Ravi S., M. Kapoor and R. Ahluwalia (2012), “The Impact of NREGS on Urbanization in India", https://www.dartmouth.edu/ neudc2012/docs/paper_299.pdf

RBI (2015), Report of the Committee on Medium-term Path on Financial Inclusion. https://rbidocs.rbi.org.in/rdocs/PublicationReport/Pdfs/FFIRA27F4530706A41A0BC394D01CB489 2CC.PDF

Reddy Y.V (2015), "Fourteenth Finance Commission: Continuity, Change and way forward", Madras School of Economics, http://www.mse.ac.in/seminar/yv\%20reddy.pdf

Sharma D.C. (2015), “India Still Struggles with Rural Doctor Shortages”, Lancet, December 12, 2015.

Sharma A. and S Chandrasekhar (2014), "Growth of the Urban Shadow, Spatial Distribution of Economic Activities and Commuting by Workers in Rural and Urban India", Indira Gandhi Institute of Development Research, WP-2014-015.

http://www.igidr.ac.in/pdf/publication/WP-2014-015.pdf

Subramanian S. and D Jayaraj (2015), "Growth and Inequality in the Distribution of India's Consumption Expenditure: 1983 to 2009-10", EPW Vol - L No. 32, August 08, 2015. PaperslSumbramanian and Jayaraj Inequality.pdf

World Bank (2015), Assessment of State Implementation of Business Reform, September 2015 http://www.worldbank.org/en/country/india/brief/department-of-industrial-policy-and-promotionreleases-assessment-of-state-implementation-of-businessreforms World Bank (2013), Urbanisation beyond Municipal Boundaries.Annex 1: 


\section{ANNEX \\ SPATIAL INEQUALITIES: \\ ACROSS STATES OR BETWEEN RURAL AND URBAN AREAS?}

1. Income inequality can be decomposed along at least in three dimensions:

- Between states, as gaps in the average income among states;

- Urban/rural divide, as gaps in the average income between rural and urban households in the same state;

- Within component: as differences across households living in the same state and belonging to the same rural/urban group.

2. While the Gini or the Theil coefficients are the most frequently inequality measures used, they do not allow the decomposition of total inequality into more than two components. Hence other measures have to be used to break down inequality between the two spatial sub-groups of the population - here states; and urban and rural areas - and the "within" component (i.e. within states, within urban areas and within rural areas). The mean logarithmic deviation (MLD) and the squared coefficient of variation (SCV) have attractive properties. (For more discussion on the properties of the inequality indices, see Mookherjee and Shorrocks, 1982). Notably, these two indices allow decomposing inequality into more dimensions.

The mean logarithmic deviation can be used as follows:

$$
\begin{gathered}
M L D=\frac{1}{N} \sum_{i=1}^{N}\left(\ln \bar{x}-\ln x_{i}\right) \\
=\underbrace{\frac{1}{N} \sum_{i=1}^{N}\left(\ln \bar{x}-\ln \bar{x}_{S_{i}}\right)}_{\text {Between states }}+\underbrace{\frac{1}{N} \sum_{i=1}^{N}\left(\ln \bar{x}_{S_{i}}-\ln \bar{x}_{R_{S_{i}}}\right)}_{\text {Urban/rural divide }}+\underbrace{\frac{1}{N} \sum_{i=1}^{N}\left(\ln \bar{x}_{R_{S_{i}}}-\ln x_{i}\right)}_{\text {Within component }}
\end{gathered}
$$

While, for the squared coefficient of variation, we have:

$$
S C V=\frac{1}{N} \frac{\sum_{i=1}^{N}\left(x_{i}-\bar{x}\right)^{2}}{\bar{x}^{2}}=\underbrace{\frac{1}{N} \frac{\sum_{i=1}^{N}\left(\bar{x}_{S_{i}}-\bar{x}\right)^{2}}{\bar{x}^{2}}}_{\text {Between states }}+\underbrace{\frac{1}{N} \frac{\sum_{i=1}^{N}\left(\bar{x}_{R_{S_{i}}}-\bar{x}_{S_{i}}\right)^{2}}{\bar{x}^{2}}}_{\text {Urban/rural divide }}+\underbrace{\frac{1}{N} \frac{\sum_{i=1}^{N}\left(x_{i}-\bar{x}_{R_{S_{i}}}\right)^{2}}{\bar{x}^{2}}}_{\text {Within component }}
$$


Where:

- $\quad x_{i}$ is the income of household $i$;

- $\quad \bar{x}_{S_{i}}$ is the average income of the state $S$ to which household $i$ belongs to;

- $\bar{x}_{R_{S_{i}}}$ is the average urban or rural income, depending on whether the household lives in a rural or a urban area, in the state $S$ to which household $i$ belongs to;

- $\quad \bar{x}$ is India's household average income.

3. Micro data for individual or household income are not available in India. Hence, the analysis is carried out with data on household consumption. This can introduce a downward bias in the measure of inequality as higher income households tend to consume a smaller part of their income. This can affect the overall inequality index as well as the three sub-components and in particular the urban/rural divide component as urban incomes are on average higher than rural ones. On the other hand, rural households may receive part of their pay in nature or self-produce part of the goods they consume. If this consumption is not captured by the survey, the urban/rural divide is overestimated.

Table 2. Percentage of inequality explained by disparities across states and the urban/rural divide

\begin{tabular}{lccc}
\hline & Between states & Urban/rural divide & Within component \\
\hline \multicolumn{4}{c}{ Mean logarithmic deviation (MLD) } \\
\hline 2004 & 14.75 & 17.58 & 67.61 \\
2012 & 18.85 & 16.46 & 64.79 \\
\hline \multicolumn{4}{c}{ Squared coefficient of variation (SCV) } \\
\hline 2004 & 7.75 & 10.00 & 82.17 \\
2012 & 9.01 & 9.30 & 81.76 \\
\hline
\end{tabular}

Source: Authors' calculation.

4. The main conclusions from this analysis are as follows:

- The most important source of income inequality is the "within component". Using various indicators of income inequality, Subramanian and Jayaraj (2015) suggest that it has increased steadily within urban areas since the early 1980s while there is less of a clear cut trend in rural areas;

- The "urban/rural divide" contributed more to spatial inequality than the "between states" component in 2004. However, the contribution of the "between states" dimension to overall inequality has increased;

5. The two approaches differ as to the contribution of spatial inequality - either the "between states" or the "rural/urban divide" - to total inequality. This is mostly due to the sensitivity of the two indicators to different forms of inequalities, with the SCV being more influenced by the presence of extremely high or to extremely low values than the MLD. 
ECO/WKP(2017)42

\section{ACRONYMS}

APMC: Agricultural Produce Market Committee

ASI: Annual Survey of Industries

BRIICS: Brazil, Russia, India, Indonesia, China, South Africa

FAO: Food and Agricultural Organization

FDI: Foreign direct investment

FY: Fiscal Year

GDP: Gross Domestic Product

GST: Good and Services Tax

IEA: International Energy Agency

INR: Indian Rupee

IT: Information technology

MLD: Mean logarithmic deviation

MPI: Multidimensional Poverty Index

MSP: Minimum Support Prices

NAM: National Agriculture Market

NITI: National Institution for Transforming India

NSSO: National Sample Survey Office

PMR: Product market regulations

PPP: Purchasing Power Parity

PSL: Priority Sector Lending

RBI: Reserve Bank of India

SCV: Squared coefficient of variation

USD: United States dollar

VAT: Value added tax

WHO: World Health Organization 